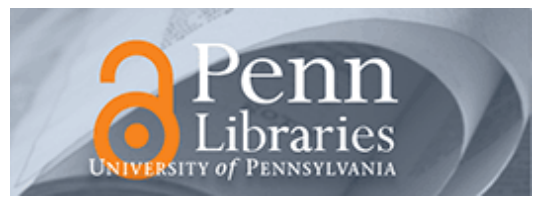

University of Pennsylvania

ScholarlyCommons

Management Papers

Wharton Faculty Research

8-2015

\title{
Network Defense: Pruning, Grafting, and Closing to Prevent Leakage of Strategic Knowledge to Rivals
}

\author{
Exequiel Hernandez \\ University of Pennsylvania \\ Wm. Gerard Sanders \\ Anja Tuschke
}

Follow this and additional works at: https://repository.upenn.edu/mgmt_papers

Part of the Business Administration, Management, and Operations Commons, Business and Corporate Communications Commons, Business Intelligence Commons, Management Information Systems Commons, Management Sciences and Quantitative Methods Commons, Organizational Behavior and Theory Commons, and the Strategic Management Policy Commons

\section{Recommended Citation}

Hernandez, E., Sanders, W., \& Tuschke, A. (2015). Network Defense: Pruning, Grafting, and Closing to Prevent Leakage of Strategic Knowledge to Rivals. Academy of Management Journal, 58 (4), 1233-1260. http://dx.doi.org/10.5465/amj.2012.0773

This paper is posted at ScholarlyCommons. https://repository.upenn.edu/mgmt_papers/336

For more information, please contact repository@pobox.upenn.edu. 


\title{
Network Defense: Pruning, Grafting, and Closing to Prevent Leakage of Strategic Knowledge to Rivals
}

\begin{abstract}
We explore how firms protect themselves from the risks of knowledge spillover to indirectly connected rivals in a network of interorganizational ties. We argue that the safeguards to limit opportunistic behavior by directly linked firms in a dyad, which have been the focus of extant research, are insufficient to overcome extra-dyadic leakage risks. Instead, firms terminate or avoid ties that expose their knowledge to indirectly linked rivals ("pruning" and "grafting") and embed themselves in dense networks ("closing") to prevent strategic knowledge spillover. Through a longitudinal study of German board interlocks during 1990-2003, we find that firms are more likely to prune, graft, and close their networks as they accumulate strategic knowledge and as the firms to which they are interlocked increasingly generate indirect ties to competitors, even when controlling for dyadic safeguards discussed by prior research. We capture strategic knowledge by tracking firms' experience in the former Warsaw Pact countries from immediately after the sudden fall of communism in 1990 until 2003. The study introduces indirect links to rivals as a source of knowledge spillover in networks, shows how firms deal with extra-dyadic risks, and provides a defensive explanation for the evolution of network composition and structure.
\end{abstract}

\section{Keywords}

closure, competition, indirect ties, knowledge spillover, networks, tie formation, tie termination

\section{Disciplines}

Business Administration, Management, and Operations | Business and Corporate Communications | Business Intelligence | Management Information Systems | Management Sciences and Quantitative Methods | Organizational Behavior and Theory | Strategic Management Policy 


\title{
Network Defense: Pruning, Grafting, and Closing to Prevent Leakage of Strategic Knowledge to Rivals
}

\author{
Exequiel Hernandez \\ The Wharton School \\ University of Pennsylvania \\ 2021 SHDH, 3620 Locust Walk \\ Philadelphia, PA 19104
}

Email: exequiel@,wharton.upenn.edu

Tel: +1 2157461984

Wm. Gerard Sanders

University of Texas at San Antonio

BB 4.01.02, One UTSA Circle

San Antonio, TX 78249

Email: gerry.sanders@utsa.edu

Tel: +12104584313

Anja Tuschke

University of Munich

Ludwigstr. 28 RG

D-80539 München, Germany

Email: tuschke@bwl.lmu.de

Tel: +498921802770

Forthcoming, Academy of Management Journal

Authors are listed alphabetically and contributed equally. We are grateful for the guidance of Associate Editor Tim Pollock and three anonymous AMJ reviewers. We thank Joel Baum, John Bechara, Youngeun Chu, Rafael Corredoira, Brent Goldfarb, Balaji Koka, Jackson Nickerson, Francisco Polidoro, Lori Rosenkopf, Aks Zaheer, and Todd Zenger; participants of seminars in Boston College, University of Munich, and Texas A\&M; participants in the 2009 Academy of International Business and Academy of Management conferences, in the 2011 Mid-Atlantic Strategy Conference, in the 2012 Midwest Strategy Meeting and Atlanta Competitive Advantage Conference, and in the 2014 Winter Strategy Conference. All errors are our own. 


\title{
Network Defense: Pruning, Grafting, and Closing to Prevent Leakage of Strategic Knowledge to Rivals
}

\begin{abstract}
We explore how firms protect themselves from the risks of knowledge spillover to indirectly connected rivals in a network of interorganizational ties. We argue that the safeguards to limit opportunistic behavior by directly linked firms in a dyad, which have been the focus of extant research, are insufficient to overcome extra-dyadic leakage risks. Instead, firms terminate or avoid ties that expose their knowledge to indirectly linked rivals (pruning and grafting) and embed themselves in dense networks (closing) to prevent strategic knowledge spillover. Through a longitudinal study of German board interlocks during 1990-2003, we find that firms are more likely to prune, graft, and close their networks as they accumulate strategic knowledge and as the firms to which they are interlocked increasingly generate indirect ties to competitors, even when controlling for dyadic safeguards discussed by prior research. We capture strategic knowledge by tracking firms' experience in the former Warsaw Pact countries from immediately after the sudden fall of communism in 1990 until 2003. The study introduces indirect links to rivals as a source of knowledge spillover in networks, shows how firms deal with extra-dyadic risks, and provides a defensive explanation for the evolution of network composition and structure.
\end{abstract}


In 2006, George Keyworth resigned from the board of directors of Hewlett-Packard amidst allegations of leaking information on the firm's long-term strategy (Murray, 2006)

In 2009, the CEO of Google, Erich Schmidt, stepped down from Apple's board due increasing rivalry between the two firms (Stone, 2009)

Between 2009 and 2012, rivals AT\&T and Sprint were indirectly linked to each other when Laura T. Tyson (director at AT\&T) and James H. Hance, Jr. (director at Sprint) both served on the board of Morgan Stanley (Morgan Stanley, 2010)

Interorganizational ties transmit knowledge that can be leveraged to make strategic decisions, develop capabilities, and scan the competitive landscape (e.g. Beckman \& Haunschild, 2002; Gulati, 2007). Yet as the opening examples suggest, they can also be conduits of undesired knowledge leakage because partners may, opportunistically or inadvertently, obtain and transmit firms' confidential information. A strand of research has focused on the defenses firms adopt to prevent the downsides of interorganizational ties. These defenses include legal tools such as contracting or intellectual property rights (Katila, Rosenberger, \& Eisenhardt, 2008; Mayer \& Salomon, 2006; Oxley \& Sampson, 2004), social mechanisms like trust or structural embeddedness (Hallen, Katila, \& Rosenberger, 2013; Polidoro, Ahuja, \& Mitchell, 2011; Zaheer, McEvily, \& Perrone, 1998), and other strategic choices such as timing or geographic colocation (Diestre \& Rajagopalan, 2012; Hallen et al., 2013; Katila et al., 2008). This work has provided a better understanding of how organizations protect their knowledge in interfirm partnerships.

We build upon but depart from these precedents in two ways. First, while research has emphasized the risks of knowledge spillover through direct ties in a dyad (Hamel, 1991; Khanna, Gulati, \& Nohria, 1998) — as in the case of Eric Schmidt linking Apple and Google — we place the spotlight on a different locus of risk arising from the broader network in which the partnership is embedded: indirect links to rivals. In this scenario a direct link may not be the problem per se but might enable leakage of the focal firm's knowledge through second order ties to the focal firm's competitors. One example is the indirect tie between AT\&T and Sprint via Morgan Stanley mentioned in the opening vignette. Networks research has long considered the upsides of second order linkages (Baker, 1990; Gulati \& Gargiulo, 1999) but given less attention 
to their downsides (Simmel, 1950), and it has not specifically considered how firms deal with second order links to competitors. These links matter because firms have a strong interest in preventing sensitive knowledge from leaking to their rivals. While the network surrounding a dyad can foster learning and trust, and be a vehicle for gathering intelligence about rivals, it also weakens the control a firm has over its network resources. For firms that possess strategically sensitive knowledge, the costs of leakage to indirectly linked competitors will be especially high, outweighing the benefits of indirect ties discussed by prior research. In these circumstances, firms are likely to adopt network defenses to limit the competitive loss of strategic knowledge.

Second, and relatedly, the defenses discussed by prior work are effective for risks posed by directly linked firms but may be insufficient to protect the firm against knowledge spillover to indirectly connected rivals. These limitations stem primarily from the lack of control a firm has over third parties, particularly competitors, to which it has no ties. For example, contractually protecting sensitive knowledge can be unusually complex when it involves a firm that is not a party in the contract, or social sanctions may be overpowered by competitive incentives. We thus propose that, as an alternative defense mechanism, firms will more directly modify the composition of the network (i.e., with whom the firm partners) or its structure (i.e., the firm's position within its network). We consider three mechanisms: Network pruning and network grafting refer to the termination and avoidance, respectively, of ties to firms that pose a risk of knowledge leakage, while network closing refers to embedding the firm in a web characterized by dense connectivity among partners.

We expect that pruning, grafting, and closing are most likely to occur as firms accumulate strategically sensitive knowledge, even when some of the defenses discussed by prior work are in place. To establish that indirect links to rivals are indeed a source of risk, we hypothesize that ties to firms creating such linkages are highly likely to be terminated in the case of existing relationships (pruning) and avoided when forming new ties (grafting). Indirect links to rivals become particularly concerning for firms accumulating experience with promising new strategies that lose value if competitors learn about them because the potential costs of leakage 
begin to outweigh the benefits of indirect links to rivals. The imperative to prune and graft the network is thus most salient for firms with increasing levels of strategic knowledge and networks characterized by a growing number of indirect ties to rivals. At the same time, pruning and grafting may not be viable safeguards in all cases because relational, legal, or organizational reasons suggest that maintaining or forming a certain relationship is preferable even if it indirectly exposes the firm to a rival. Network closing thus becomes a complementary source of knowledge protection because it embeds firms in a set of dense relationships where monitoring of other parties is more plausible and flows of information are more circumscribed (Baker, 1990; Lin, 2001). We thus expect that network closure will increase over time for firms with increasing levels of indirect links to rivals and of strategically sensitive knowledge. Knowing when firms prune, graft, and close matters because, while network ties and structures dynamically change in general, it is less clear which ties and what conditions prompt firms to take such dramatic actions - particularly in the face of competitive dynamics.

We found empirical support for our hypotheses through a longitudinal analysis of tie termination, tie formation, and closure in the board network of large German firms between 1990 and 2003. We operationalized strategic knowledge by observing the accumulation of firms' experience in former Warsaw Pact countries from immediately after the sudden fall of communism in 1990 until 2003. We observed this accumulation without left censoring because these markets were untapped by Western firms prior to 1990. Although the tensions that underlie our questions occur in a variety of networks (e.g. alliances, investment syndicates), interfirm board ties are a particularly amenable setting to study these issues. These ties are conduits of knowledge on momentous and strategically sensitive topics like acquisitions, market positioning, and other major investments (e.g. Beckman \& Haunschild, 2002; Davis \& Greve, 1997; Palmer, Jennings, \& Zhou, 1993). Since direct linkages to competitors are typically prohibited, indirect links are the primary sources of potential leakages to rivals. The required legal disclosures on director appointments allow firms to be aware of network paths to competitors, so indirect ties are a tangible source of risk in this context. Yet many of the safeguards used in other networks 
are present in board ties as well-legal protections such as confidentiality agreements and disclosures of related business interests (Carter \& Lorsch, 2004); or social mechanisms like trust and links to prominent partners (Davis \& Mizruchi, 1999).

This paper contributes to prior work in several ways. First, our study introduces the risks posed by indirect ties to rivals and the network defenses firms utilize to mitigate those risks ${ }^{1}$. This contrasts with prior literature focused on the potential benefits of second-order ties (e.g. Granovetter, 1992). Second, we show that safeguards designed for risks within dyads are incomplete in defending against second-order links to rivals, prompting firms to more directly manage the composition and structure of their networks to deal with indirect knowledge spillover. Third, this study demonstrates how competitive, defensive considerations that lead to protective behavior are drivers of network evolution. For example, it speaks to research on the closure of open network structures (Burt, 2002) by demonstrating that structural holes may be eliminated by the very firms that span them in order to secure strategic knowledge from diffusing to rivals. This defensive view contrasts with the tendency to explain network change as a function of positive motives like resource sharing or joint value creation, providing a more balanced consideration of the upsides and downsides of ties to the literature on network dynamics (e.g. Sytch \& Tatarynowicz, 2013).

\section{Research Setting: The Opening of Eastern Europe and the German Board Network}

After the sudden and unexpected fall of communism in 1990 Western firms had the opportunity to expand into untapped foreign countries with significant economic potential. However, those countries were essentially closed to Western investment before 1990, thereby increasing potential entrants' uncertainty about the business risks in these locations. The prospect of entering former Warsaw Pact countries (hereafter Eastern Europe) was particularly intriguing for German firms in light of their proximity to the region (Marin, 2011), but companies also faced unforeseen cultural and institutional differences, problematic relations with local partners, and volatile market conditions (Flaig, 2006; Prochnow, 2004; Stevenson, 1993). Hence,

\footnotetext{
${ }^{1}$ At the time this paper was accepted for publication, were made aware of a related study on the negative effects of indirect ties to rivals on startup innovation (Cox-Pahnke, McDonald, Wang, \& Hallen, 2014).
} 
information about these locations was at a premium during this period.

Eastern Europe became a critical topic in German boardrooms, where high-level strategic issues were decided. As background for this study we conducted interviews with directors of several German firms. Directors with first-hand experience in Eastern Europe helped firms better assess the risks and opportunities of investments in this region and get approval for their entry strategies. For instance, one individual we interviewed remarked, "board members have experiences in specific regions and can provide input about their experiences, likely problems, etc. Therefore, there are often discussions in the boardroom where board members share their regional experience.” Another one stated: “...one of the most important tasks of a board member is to ask the right questions... Experience in these markets helps you to ask the right questions." Even more to the point, one board chairperson stated: "You cannot expect the CEO to come to the board and say we could go to ... a former Warsaw Pact country or to someplace in Central Europe - let's discuss the alternatives... There will be a regional strategy, and it is the result of a process within the company; the strategy will not have been crafted by or even decided by the CEO himself... However, given helpful input from the board, there may be new thoughts added to a regional strategy."

The types of knowledge about Eastern Europe that were transferred via the network can be broken in a few categories. One had to do with the process of investing in a transition economy: dealing with legal hurdles, establishing connections to new suppliers or customers, or adapting to cultural and other practices. Another subject had to do with market conditions: business and political risks, growth opportunities, and local competition. In addition, executives and directors wanted to know how Eastern European activities fit with domestic operations (e.g., labor relations). A good portion of the knowledge was regional in nature because all the countries inherited some of the institutional infrastructure of the former Soviet Union. Yet differences within the region were significant, as some countries like the Czech Republic, Estonia, and Latvia reformed quickly while others showed less interest in moving towards capitalism (Iankova, 2002). The early reformers often invested in their infrastructure and 
educational system, thus making these markets more attractive for foreign investments. In addition to the speed of transition, the logic of reform itself differed across countries and created heterogeneity in the emphasis on social vs. market imperatives, openness to foreign assistance, and other factors (Orenstein, 2001).

The knowledge necessary to invest in these countries was highly tacit and hence more easily transmitted through the rich medium of a personal board connection (Daft \& Lengel, 1986; Kogut \& Zander, 1992). There was one more type of information that was more codifiable but no less important: knowing what plans a firm had in the region, in particular a competitor's expansion strategy. All of these types of knowledge were sensitive in nature and worth protecting. Our interviewees revealed that firms are careful to safeguard such strategic knowledge from leaking to competitors through the board network. For example, one director stated, "We need to protect our knowledge. There are only very few firms in our field of business. However, we still have to have safeguards in place."

\section{BACKGROUND LITERATURE}

\section{Knowledge Protection and Indirect Network Ties}

Ties between organizations are viewed as the plumbing through which organizations can learn from each other (Levitt \& March, 1988; Podolny, 2001). Research demonstrates that networks reduce the cost of searching for relevant knowledge and enable knowledge transfer across organizational boundaries (Beckman \& Haunschild, 2002; Mizruchi, 1996), influencing a range of positive outcomes such as innovation (Ahuja 2000), strategic choice (Haunschild, 1994), and performance (Zaheer \& Bell 2005). However, network ties can also impair the strategic value of the firm's knowledge because, once disclosed to a partner or exposed to the broader network, knowledge is hard to protect from further diffusion and loses its uniqueness (Arrow, 1974; Dushnitsky \& Shaver, 2009; Katila et al., 2008). Thus firms face a tension between the benefits and risks of participating in interorganizational networks.

A body of research in this domain focuses on the safeguards firms establish to protect their knowledge from unwanted diffusion, particularly to competitors. Legal tools such as 
contracting, governance modes, limiting scope, or intellectual property rights help anticipate or adjudicate problems that arise after tie formation (e.g. Oxley \& Sampson, 2004; Mayer \& Salomon, 2006; Katila et al., 2008). Social mechanisms including trust, ties to central partners, or relational and structural embeddedness mitigate hazards through social control (e.g. Hallen et al., 2013; Polidoro et al., 2011; Zaheer et al. 1998). Other strategic safeguards include the timing of alliance formation, goal adjustment, and geographic colocation (e.g. Katila et al. 2008; Diestre \& Rajagopalan, 2012; Hallen et al., 2013). Empirical papers often explain how certain safeguards impact tie formation or some type of performance outcome. These important precedents have two commonalities. First, they focus on the risks of knowledge leakage within the dyad. A direct partner represents a real source of concern because it may behave opportunistically or be a direct competitor in the marketplace (e.g. Hamel, 1991; Polidoro et al. 2011). Second, and relatedly, the defenses proposed by this work are mainly designed to mitigate risks within the dyad. For example, a contract can be written with the direct partner because it is a party to the transaction, or over time trust can develop by repeatedly working together (Gulati, 1995).

Yet risks of unwanted knowledge leakage also lie in the broader network in which the dyad is embedded. Namely, firms can be exposed to competitors when their first-order partners establish second order paths to their rivals. We are not the first to point out the existence or relevance of second order ties. The entire literature on social networks is predicated on the idea that the structure surrounding a dyad matters (e.g. Simmel 1950). Research on tie formation and dissolution discusses the role of structural embeddedness, where linkages to common third parties provide social control that makes parties feel safer and more trusting, lending cohesion and stability to the relationship (e.g. Granovetter, 1992; Gulati \& Gargiulo, 1999; Polidoro et al. 2011). And work on knowledge transfer via networks is based on the fact that network paths beyond the dyad are essential for the diffusion of information and interorganizational learning (Burt, 1992; Podolny, 2001). From a competition standpoint, indirect links may help a focal firm gain useful intelligence about rivals' knowledge and strategies. In most cases, research focuses on the positive outcomes of these second or third order ties. However, while indirect linkages in 
general may be beneficial, if they link a focal firm to a rival they can be dangerous from a knowledge standpoint because they increase the risk that the firm's strategic knowledge will leak to an undesired recipient. This risk may not be a concern if the defensive mechanisms to keep direct partners in check were effective in preventing second order leakage. We explore reasons why this may not always be the case by studying conditions under which the costs of indirect ties outweigh their benefits.

Board Interlock Networks. We study how competitive tension plays out in a network of board interlocks. Boardroom discussions often focus on high-level, momentous strategic issues that determine the direction, scope, and success of the firm. Directors have a duty to carefully consider these issues and offer competent advice (Westphal, 1999). The network of board ties is an important source of vicarious learning for firms because board members with experience in specific domains have a high degree of credibility (e.g. Davis \& Greve, 1997; Tuschke, Sanders, $\&$ Hernandez, 2014). These patterns of learning and practice diffusion imply that firms possessing knowledge face some degree of spillover risk through their board networks (Murray, 2006), though research has not systematically explored this possibility. Managers and directors involved in the board network are aware of the various linkages they create. In the process of being vetted, potential new directors must report any other boards on which they serve. After the appointment, firms are required to disclose the names of their executives and directors, the employment relationships of every officer, and the current directorships the individual holds. In addition, the network of board ties among large firms is a rather small, elite world in which awareness of 'who serves where' is quite high. Thus the opportunities for knowledge exchange and leakage are real in this kind of network.

Strategic Experience and Knowledge. Because this study focuses on experience in Eastern Europe as an indicator of strategic knowledge, we theoretically establish the connection between experience and knowledge. We draw on the behavioral theory of the firm, which defines organizational learning as the systematic change in a firm's knowledge base occurring as a function of prior experience (Argote, 1999). Our study is concerned with knowledge that is 
strategic (vs. technical) in nature, enabling firms to engage in actions that influence growth and performance. The behavioral theory has a well-validated notion that, while knowledge per se is unobservable, experience with an issue is a very strong proxy for knowledge (e.g. Levitt \& March, 1988). Firms obtain and accumulate knowledge through experience, by which they develop understanding, routines, and resources related to a particular domain of action (Nelson \& Winter, 1982). As research on experiential learning has shown, knowledge gained from experience can be applied to future challenges and opportunities similar in nature to prior actions (e.g. Amburgey \& Miner, 1992). Based on these theoretical foundations, we define strategic knowledge as the information and know-how embodied in a firm's accumulated experience with a strategic issue - which we operationalize as foreign experience in Eastern Europe.

We propose that strategic experience gained outside of the network domain also has value because it is a resource prized by other network participants. The experiential learning of one firm becomes the potential source of vicarious learning for another (Argote \& Miron-Spektor, 2011). Network ties such as board interlocks are the most powerful channels through which vicarious learning occurs because they bring together individuals who share experiences, advice, and know-how. If the knowledge embodied in the first-hand experience of a firm is valuable not just for future learning but also because other network participants prize it, such knowledge is threatened when the odds of it leaking to an undesirable receiver are high.

\section{HYPOTHESES}

We begin by establishing a baseline expectation about how knowledge affects tie dissolution and formation. Accumulating strategic knowledge gives rise to two opposing imperatives. On the one hand, the firm has a network resource that it does not want its rivals to obtain (e.g. Katila et al. 2008). On the other hand, the firm is a more attractive potential partner because of its valuable know-how (Ahuja, 2000). Tie terminations occur as the firm eliminates connections that pose a threat to its accumulated knowledge, while tie additions occur as the firm gains opportunities for new partnerships. In a board network, this happens as firms change the composition of their boards or as the firm's managers - who have first-hand experience with the 
strategic issue — become attractive directors for other firms. We are agnostic about the ratio of terminations to additions or whether one leads to the other, and only expect that both will increase. This idea is not original to our study but we deem it important to connect our paper to previous work (Katila et al. 2008, Polidoro et al. 2011). We thus present the following baseline hypothesis: as firms accumulate strategic experience (e.g. Eastern European market entry), their board networks will manifest greater churn through more tie terminations and additions.

\section{Pruning and Grafting}

The core question we address is how firms protect knowledge from diffusing to rivals beyond the dyad. Second order links threaten the strategic value of a firm's knowledge because indirect, bridging ties are the primary conduits of diffusion beyond the firm's immediate relationships (Granovetter, 1973; Burt, 1992). The literature on knowledge transfer emphasizes the role of network paths beyond the dyad as crucial transmission channels, and empirical studies on interorganizational ties provide support for this idea (Bell \& Zaheer, 2007; Rosenkopf \& Almeida, 2003). For firms seeking knowledge, the broader network is a valuable source of learning opportunities and of intelligence about rivals. But from the perspective of the possessor of strategic knowledge, the broader network can also become a source of unwanted exposure. While not all second order paths are inherently risky, firms are sensitive to those that lead to competitors because the advantage they may have in the marketplace depends on the inability of rivals to tap into the firms' knowledge or replicate its actions (e.g. Grant, 1996; Kogut \& Zander, 1992). For instance, research shows that leakage of sensitive knowledge through indirect ties is detrimental to firm innovation (Cox-Pahnke et al., 2014). Hence, firms are likely to take actions to prevent indirect ties to rivals from undermining their strategic knowledge.

While concerns about collusion prohibit or strongly discourage direct links to competitors through board interlocks, indirect ties to rivals are not uncommon and pose the primary threat in this type of network. We already provided one illustration in the introduction with the case of AT\&T and Sprint being linked through Morgan Stanley. Another example is the case of Lowe's and Home Depot between 2007 and 2011: Stephen Page, a director at Lowe's at that time (2003- 
2011) served as director at Liberty Mutual Insurance between 2001 and 2012. Between 2007 and 2011, Annette Verschuren, a senior officer of Home Depot (1996-2011), also served on the board of Liberty Mutual Insurance, thus creating an indirect link between rivals. These two examples correspond to the solid arrows in Figure 1, which also illustrates general ways in which indirect links among competitors can happen. For instance, the dashed arrows show how a top manager of Firm $\mathrm{B}$ could be on the board of firm $\mathrm{Z}$ with an independent director who also serves on the board of B's rival (firm A).

Insert Figure 1 Here

Our interviews with directors and managers revealed that they are aware of and seek to avoid the threats posed by indirect ties to competitors. For example, when asked about the role of indirect ties in establishing new interlocks, one Chairman responded: "of course, ties to competitors play an important role. We try not to establish links to competitors." When asked to clarify whether this referred specifically to indirect ties, he said: "As I said, we are very cautious in this respect." Strategically sensitive information in our context could refer to the sequence and timing of entry into different Eastern European countries or to intelligence about key suppliers or customers in individual host markets. Competitors from the home market might be interested in acquiring or in establishing an alliance with the focal firm's partners in the target market. In the case of an acquisition, for example, firms are interested in preventing information about a potential offer from leaking to their competitors.

We posit that firms can protect themselves from the risks of indirect links to rivals by modifying the composition of their ego networks through two mechanisms: pruning and grafting. Pruning refers to dissolving interlocks, and we argue that such an action is more likely as the firms to which directors connect the focal firm increasingly create paths to rivals. Dissolutions may occur based on mutual consent, at the request of the focal firm, or be the result of not renewing a directorship when it is due to expire. For instance, in the late 1990's a top manager of Deutsche Bank stepped down from the board of Thyssen after it was deemed that he posed a risk 
of transmitting sensitive information to Krupp—-Thyssen's rival—during a takeover attempt (Der Spiegel, 1997). Grafting refers to creating new interlocks by appointing directors that establish new links to other firms. The risks of indirect links to rivals are salient at the time of tie formation, when firms seek to avoid interlocks that create conflicts with rivals. From a more constructive point of view, firms are more likely to approve new interlocks to firms that generate relatively few indirect ties to rivals. We label these actions as network pruning and grafting because they reflect a defensive decision that alters the composition of the firm's network.

While firms have reasonable latitude to prune and graft, eliminating an existing tie or avoiding a new one because it creates indirect links to rivals is a rather drastic decision and many other considerations could be at play. One could argue that the dyadic legal, social, and strategic defenses studied by prior research are sufficient to protect from the risks of second order paths to rivals. For instance, contracts contain clauses about confidentiality or fiduciary responsibility that cover the transmission of knowledge to third parties. And trust is a powerful social mechanism that reduces opportunism. Longstanding friendships and commitments may be violated and valuable sources of learning eliminated when ties are terminated, and forming a new tie may be justified if the new partner brings resources that compensate for second order exposure to rivals. These considerations are warranted and form a valid null to our hypotheses. Yet there is a different degree of control when it comes to the behaviors of directly linked firms versus contingencies arising from the broader network. For example, contracts can only be written between parties directly involved in a task and are difficult to enforce when it comes to a third party. And research has discussed the difficulty of contractually protecting knowledge with strategic and tacit attributes (e.g. Kogut \& Zander, 1992). High trust between two firms does not preclude trust between one of the firms and a third party over which the focal firm has little control, which is troublesome when that third party is a rival. Hence, although the defensive mechanisms discussed by prior work are useful, additional risks arise when looking beyond the dyad that may require more drastic defenses.

We are agnostic about the motivations of network participants and do not assume 
malicious or opportunistic intent. In fact, a firm's knowledge can be compromised inadvertently. For instance, a director might unknowingly reveal sensitive information as s/he 'switches hats' in supervising different firms throughout the network, or the simple appearance of conflicts of interest despite individual integrity may be sufficient to affect tie formation or dissolution. Defenses like contracts and trust may be less effective against inadvertent leakage, whereas pruning and grafting are more secure in this regard. In addition, while linkages to competitors are thought to reduce competitive uncertainty through tacit collusion or mutual forbearance (Gimeno, 2004), these considerations must be weighed against the risk of undermining the strategic value of knowledge. Thus we are also agnostic as to the baseline level of 'acceptable' forbearance that firms desire. Rather, the threshold of what is considered acceptable changes as various risks — including knowledge spillover - accumulate over time.

Hla: The more indirect links to the focal firm's competitors an existing interlock with another firm creates, the greater the likelihood that the interlock to that firm will be terminated.

$H 1 b$ : The fewer indirect links to the focal firm's competitors a potentially new interlock with another firm creates, the greater the likelihood that an interlock to that firm will be established.

So far we have held the amount of knowledge a firm possesses constant, which leaves open the possibility that indirect links to rivals affect tie terminations and additions for reasons unrelated to knowledge. Yet our theoretical interest is in how firms seek to protect their strategic knowledge, and firms develop experience with a given strategic issue at different rates. Per the baseline expectation, the fear that something valuable might leak and the competitive consequences of such leakage increase as the firm accumulates knowledge worth protecting - in our setting, as the firm obtains experience in transition economies. The more knowledge firms accumulate, the more likely that indirect links to competitors will be associated with tie terminations and that new ties with firms producing high levels of exposure to competitors will be avoided. This joint effect — high experience and high indirect links — indicates a significant risk of undesirable knowledge spillover. The potential for leakage becomes more real when the focal firm has more of something valuable to lose and many network paths making that possible 
loss probable - the benefits of indirect ties are outweighed by the risk of undesired outflows of knowledge. This logic leads to the following hypotheses:

H2a: The positive relationship between the indirect links to the focal firm's competitors generated by an existing interlock with another firm and the likelihood that the interlock to that firm will be terminated (per Hla) will increase as the firm accumulates strategic experience (e.g., Eastern European market entry).

$H 2 b$ : The negative relationship between the indirect links to the focal firm's competitors generated by a potentially new interlock with another firm and the likelihood that the interlock to that firm will be established (per H1b) will increase as the firm accumulates strategic experience (e.g., Eastern European market entry).

\section{Network Closing}

Several constraints complicate the considerations involved in unilaterally pruning and grafting board ties for a single reason such as preventing an indirect link to a rival. These include personal relationships between executives and directors (e.g. Westphal, 1999), relational or structural embeddedness that makes it hard to terminate a relationship without suffering reputational penalties (e.g. Hallen et al. 2013), legal contracts that limit the flexibility to terminate a tie, or a desire to maintain or establish a tie to a firm that provides valuable vicarious learning (e.g. Beckman \& Haunschild, 2002). In light of these considerations, we propose that firms can still safeguard strategic knowledge even when indirect ties to competitors cannot be eliminated or avoided. Firms can accomplish this by seeking to embed themselves in a closed, dense network in which social monitoring is more prevalent and knowledge diffusion is more circumscribed (e.g. Lin, 2001). The extent of network closure or openness has received a great deal of attention in research because these positions give rise to different kinds of benefits (Burt, 2005). Our contribution to this work is to point out that closure can function as a defensive network tool when risks of unwanted knowledge spillover are high. Research has found that closure provides two types of benefits: a greater ability to transfer fine-grained, tacit knowledge (Ahuja, 2000) and a greater degree of social control (Coleman, 1988). Both are relevant for protecting knowledge from diffusing to rivals.

The key risk posed by second order ties to rivals is that knowledge will diffuse beyond 
the firm's desirable circle of ties to a recipient that competes directly with the firm in the market. This risk can be mitigated when there is a high degree of agreement among all firms in an ego network regarding acceptable behavior and when the firm can more easily monitor those behaviors. These conditions facilitate social control by allowing the firm to exert reputational and normative pressures on other firms to protect its interests (e.g. Coleman, 1988; Lin, 2001). In terms of knowledge control, information within densely linked networks tends to be more homogenous and circumscribed (e.g. Burt, 1992; Ahuja, 2000). This could be a disadvantage when firms seek to expand their knowledge and creativity, but is beneficial from a defensive standpoint. Because the knowledge of the firm is contained within a tighter set of ties, monitoring its diffusion is easier than if the firm's network were more open. Echoing these ideas, Lin (2001: 27) makes an important distinction between the objectives of preserving and obtaining resources in networks and concludes that "for preserving or maintaining resources...denser networks may have an advantage" over more open networks.

To benefit from this kind of knowledge protection, a firm experiencing an increasing threat of unwanted knowledge leakage to rivals will be more likely to engage in behaviors that increase ego network closure. Closure is a complex structural arrangement that depends on the motivations and actions of multiple network actors, so firms have a significantly weaker ability to orchestrate closure than to prune and graft. However, the influence they do have over closure in board interlock networks comes from the ongoing process of director appointments and departures. If this process were random, we would expect no discernible effect on the network structure. But in a setting in which there is a strong motivation to protect strategic knowledge from leaking to rivals, decisions about directorships are not random. Instead, firms will increase their reliance on their existing, trusted circle of interlock network ties to manage the risk of losing valuable knowledge (Uzzi, 1999; Beckman, Haunschild, \& Phillips, 2004). This is manifested in two ways that increase closure.

When it comes to filling vacancies or appointing new directors, a common way to rely on existing relationships is to exchange referrals with existing directors and managers in the current 
board network. Research documents that such referral seeking and giving is indeed one of the important mechanisms explaining board tie formation (Koskinen \& Edling, 2012; McDonald \& Westphal, 2010; Useem, 1984). The reliance on trusted referrals is particularly salient when the need to protect (instead of seek) knowledge is paramount, and will be more likely to produce a denser web of relations because it reinforces ties amongst the firms' immediate, pre-existing relations. A manager who serves on the board of another firm may, for instance, rely on trusted members of that board to solicit referrals for a vacant directorship at her own firm. Often, the suggested candidates will not only be personally known to those who refer them but will also be linked to them through interlocks. A similar reasoning applies to director departures. Given the constraints firms have over unilaterally ending ties, the focal firm has the most social and strategic latitude in ending linkages to other firms that are more isolated from its existing core of well-established relationships. These peripheral firms (in the focal firm's ego network) are also socially difficult to monitor, and their elimination thus reinforces closure amongst the core circle of interlock relations. These dynamics of director appointments and departures are not the same as pruning and closing as in $\mathrm{H} 1-\mathrm{H} 2$ because they do not refer to eliminating or avoiding those creating indirect links to rivals. Instead, they apply to any linkage that can reinforce the existing set of trusted ties amongst the focal firms' network of non-rivals - even and especially in the presence of indirect links to rivals ${ }^{2}$. Hence, they are an additional defensive layer to 'seal off' the network against unwanted knowledge leakage.

As before, we view the risk of leakage arising from two conditions. Organizations accumulating strategic experience have a greater imperative to be protective. However, the baseline hypothesis suggests that knowledge accumulation increases tie additions and terminations and both could affect network closure, so its independent effect on closure is unclear. But high strategic knowledge levels coupled with increasing numbers of indirect links to competitors make it more probable that the firm's knowledge will fall into undesirable hands and

\footnotetext{
${ }^{2}$ We are not speaking of the firm orchestrating linkages involving its rivals, such as asking a director tied to a nonrival firm to create a tie to a rival firm, or to encourage linkages between two of the focal firms rivals. We are referring to appointing and ending directorships among the firm and its non-rival firms to which there are preexisting interlocks in the ego network.
} 
strongly prompts the firm be protective, pushing it to try and close its network. Thus we propose the following interaction effect:

H3: As firms accumulate strategic experience (e.g., Eastern European market entry), their ego networks become more closed as the firms to which they are interlocked generate more indirect links to the focal firms' rivals.

\section{DATA AND METHODS}

In the German corporate governance system, companies with publicly traded shares have a two-tier board structure comprising a supervisory board ("Aufsichtsrat") and a management board ("Vorstand"). The supervisory board plays the same role as the board of directors in the U.S., while the management board is equivalent to U.S. top management teams. Officers from the management board cannot serve on the supervisory board of their own firm, but they can be directors in the supervisory boards of other organizations. The supervisory boards of large firms are usually composed of top executives from other firms (i.e., members of other firms' management boards) and non-executive experts. Both boards work together closely to craft and develop firm strategy and the supervisory board meets in concert with the regular meetings of the supervisory board. As in other Western governance systems, the management board is accountable for operational and strategic decision-making. Unlike in the U.S., the size of the supervisory board is legally dictated according to firm size. Yet research has demonstrated that ideas, strategies, and policies diffuse through German board networks in much the same was as they do in other contexts (Sanders \& Tuschke, 2007), which was validated through our interviews with German executives and directors.

\section{Qualitative Information from Interviews}

We conducted nine interviews with members of German supervisory boards during 20092010, four of which specifically addressed Eastern European strategy. These were wellpositioned individuals, such as CEOs or the Chairperson of one of the five largest firms in Germany, and were well acquainted with the context and the time period. The purpose was to learn how strategic knowledge — and the subject of Eastern Europe in particular — was transferred through board ties and how this might impact the network. The meetings were exploratory in 
nature; we make no claims that these interviews constituted a qualitative or grounded theory study in and of themselves. As the quotes included earlier in the paper show, the clear thrust of the responses was that discussions of Eastern Europe definitely took place in the boardroom, that they were important during this period, and that the protection of strategic knowledge (from indirect links to rivals) was relevant. We also interviewed four board members of U.S. Fortune 500 companies in 2013, including two former CEOs. Three firms had entered at least one country in Eastern Europe. Such interviews helped us understand if what we observed in Germany was applicable to other settings. The meetings suggested that emerging market entry was indeed a topic of discussion in U.S. boards, that directors eagerly attempt to learn from each other, that regional strategies are a key element of a firm's overall strategy, and that firms are protective of their knowledge regarding such strategies.

\section{Quantitative Data for Empirical Analysis}

We obtained yearly data on the board interlocks of German firms and their experience in Eastern Europe between 1990 and 2003 based on the dataset used by Tuschke, Sanders, and Hernandez (2014). The sampling frame consisted of firms listed in the DAX 100 — an index of the largest publicly traded German corporations. These firms are the most likely to have the resources to engage in risky foreign investments and are the most involved in the German interlock structure (Jürgens, Naumann, \& Rupp, 2000). To ensure that we observed firms with latitude in forming board ties and making FDI decisions, we removed seven that were subsidiaries of other firms. For the remaining companies, we obtained data on foreign investments in the 21 former Warsaw Pact countries ${ }^{3}$. Since our sample begins in 1990, the foreign experience data basically avoids left censoring because only four firms had invested (to a very limited extent) behind the iron curtain prior to 1990. Thus we assess how the network evolves in response to experience in a well-controlled setting by encompassing a period during which knowledge went from virtually non-existent to more widely available.

\footnotetext{
${ }^{3}$ The 21 countries are: Armenia, Azerbaijan, Belarus, Bulgaria, Czech Republic, Estonia, Georgia, Hungary, Kazakhstan, Kyrgyzstan, Latvia, Lithuania, Moldova, Romania, Poland, Russia, Slovakia, Tadzhikistan, Turkmenistan, Ukraine, and Uzbekistan.
} 
We triangulated from multiple sources to get information on firms' investments in Eastern Europe. We began with annual reports, where some organizations provide a complete list of ownership shares in foreign subsidiaries. However, large firms tend to restrict disclosure to selected investments. To get a more accurate count, we contacted each firm's IR department and asked for detailed information on entries into the 21 countries. We also searched LexisNexis for press reports containing the name of the company combined with terms like 'entry, FDI, investment, plant, acquisition, Eastern Europe.' We complemented this data with information on each firm's investments as reported in the Handbook of German Listed Companies. We then contacted the firms again and asked them to confirm or correct our information. Finally, we contacted the registration offices of the district courts in which firms were required to file reports of their foreign activities and looked at the firms' original filings to correct inconsistencies and reduce missing data. This exhaustive process resulted in complete data for 71 firms compared to 82 firms in the study by Tuschke et al. (2014). The 11 firms not included in this study were dropped because complete network data to calculate primary measures was unavailable. The majority of variables in this study differ from those in Tuschke et al. (2014) because the research questions differ substantially, except for four control variables that we mention below.

\section{Variables of Interest}

To create the network measures, we constructed 14 yearly $n{ }^{*} n$ matrices, where $n$ is the number of firms in any given year. The sample began with 71 firms in 1990 and ended with 68 firms in 2003 because three companies were acquired during the period. We counted a board interlock between two firms when an individual affiliated with one firm's supervisory or management board served on the supervisory board of another firm (Mizruchi, 1996). Firms A and $\mathrm{B}$ are assigned a value of one in the $n^{*} n$ matrix if an individual affiliated with $\mathrm{A}$ is on the board of B or vice versa, and assigned a value of zero otherwise. Directorships have to be reported in annual reports by law, so there is no missing data on board ties. In describing the variables in this section, we periodically refer to the firms to which a focal firm has interlocks as 'partners' to preserve the technical meaning of nodes linked by ties in an interfirm network, to 
distinguish the focal firm from other firms, and as shorthand for 'firms linked via board interlocks' to make the wording less onerous.

Tie terminations and additions: We first analyzed the cessation or origination of ties between pairs of firms. The variable terminate $_{i j t}$ is coded as 1 if firm $i$ and $j$ cease having a board tie in year $t$ and 0 otherwise. Ties had to be discontinued for two years or more to be considered terminated, since a one-year interruption did not clearly signal the intent to end the relationship. We observe each pair of firms with a board tie from 1990 or the year of inception until it is terminated. The variable added $_{i j t}$ is coded as 1 if firm $i$ and $j$ create a new board tie in year $t$ and 0 otherwise. As with terminations, we only counted as additions cases in which a pair of firms established a tie for at least two continuous years. We observed 853 tie terminations and 733 additions in our sample. The results are robust if we consider ties as added or terminated after only a single year gap.

Network closure: We used Burt's (1992) measure of constraint:

$$
C_{i}=\sum_{j}\left(p_{i j}+\sum_{q} p_{i q} * p_{q i}\right)^{2}
$$

In this formula, $p_{i j}$ is the proportion of focal firm $i$ 's total ties invested in partner firm $j$, $p_{i q}$ is the proportion of firm $i$ 's total ties invested in a third party $q$, and $p_{q i}$ is the proportion of firm $q$ 's total ties invested in firm $i$. This measure captures the extent to which firm $i$ 's direct ties to its partners are redundant given the number of direct ties between firm $i$ 's alters. The variable ranges from zero to one, with increasing values indicating higher closure.

Indirect competitor links (ICL): We defined rivals as firms operating in the same industry based on their primary 6 digit GICS code. The GICS system is akin to the SIC or NAICS schemes but has wider use outside the U.S. GICS codes include 10 "sectors" (2 digit), 24 “industry groups" (4 digit), 68 "industries" (6 digit), and 154 "sub-industries" (8 digit). We opted for the 6-digit "industries" because they capture firms at a sufficiently detailed level so that categories are distinct and firms realistically compete in the same spaces (e.g. "beverages" vs. 
"food products"). ${ }^{4}$ Our choice of 6 digit codes seems to be reasonably aligned with the notion that firms are prohibited from forming and seek to avoid direct board interlocks within industries. Only $4 \%$ of board ties in the data were between firms in the same 6-digit GICS industry (15\% at the 2 digit level). This may represent a small degree of measurement error, but the results are robust if we exclude these cases from our analysis. In contrast, indirect links between firms in the same 6-digit industry are more common, with each exposed to an average of 4.5 links in their ego networks (just over 0.5 indirect links per direct partner).

Based on this classification system, we created two measures of indirect competitor links. For each dyad in which $i$ is the focal firm and $j$ is the existing or potential firm linked via an interlock, we count the number of ties firm $j$ has to firms operating in the same industry as firm $i$. To illustrate, Figure 2 shows how IWKA from the machinery industry is tied to Dyckerhoff in the construction materials industry. Dyckerhoff, in turn, is connected to Klöckner and Dürr, both of which are in the machinery industry like IWKA. Thus, Dyckerhoff generates two indirect competitor links for IWKA. This measure is used to test $\mathrm{H} 1-\mathrm{H} 2$ at the dyad level. To test $\mathrm{H} 3$ at the ego network level, we created the following measure:

$$
\sum_{j} \frac{\text { indirect ties to rivals }_{\mathrm{ij}} * \text { ties }_{\mathrm{j}}}{{\text { indirect } \text { ties }_{\mathrm{i}}}}
$$

Here, indirect ties to rivals $s_{i j}$ is the number of indirect links to focal firm $i$ 's competitors created by its partner $j$ ties $_{j}$ is the total number of direct interlocks that firm $j$ has, and indirect ties $_{i}$ is the total number of indirect (second order) ties that focal firm $i$ has regardless of industry. This is summed for all of the focal firm's partners. The intuition for weighting indirect competitor ties by ties $_{j}$ is that, the more others to which firm $j$ can disclose information, the more firm $j$ compounds the baseline risk of leakage for the focal firm. The results are robust if we use a simpler, unweighted measure of the average indirect competitor links per interlocked partner.

Insert Figure 2 Here

\footnotetext{
${ }^{4}$ We did not employ 8 digit codes because in our data the vast majority of 6 digit industries represented do not include more than one "sub industry" (there are 35 6-digit industries in our sample and 448 -digit sub industries).
} 
Strategic experience. We captured Eastern European (EE) experience as the logged number of countries in which firm $i$ had engaged in FDI as of year $t$. Logging gives more weight to earlier experiences because those are the most formative sources of strategic knowledge (Argote, 1999), consistent with research on diminishing returns to learning from experience (Hatch \& Dyer, 2004). The measure serves as a good indicator of progression along the learning curve. Since we do not double count entries into specific countries, firms with higher values of this variable have entered many different countries and possess a broader picture of what it takes to operate in transition economies. We verified that highly experienced firms had progressively moved beyond the most popular markets. Such firms should have more incentives to protect their accumulated experiences than their less experienced counterparts. We were initially agnostic as to the functional form of the experience measure and chose among several candidates using the Bayesian Information Criteria (BIC) and Akaike's Information Criteria (AIC) as indicators of model fit. We considered six alternatives to our chosen measure: a count of countries entered (non-logged), a count of countries weighted by a linear decay function to account for organizational forgetting (de Holan \& Phillips, 2004), a logged version of this organizational forgetting measure, and three separate logged counts of countries weighted by relevant target country characteristics (distance from Germany, GDP, and country risk). We report below on the robustness of our findings to these alternative measures.

\section{Estimation}

We are interested in two different types of dependent variables, each requiring a different data structure and estimator. We describe the estimation techniques before detailing the control variables because the types of controls and the level at which they are measured differ slightly for different dependent variables. All independent and control variables are lagged by a year.

Dyadic tie changes: The first set of dependent variables operate at the dyadic level, and we estimated equations of the following form:

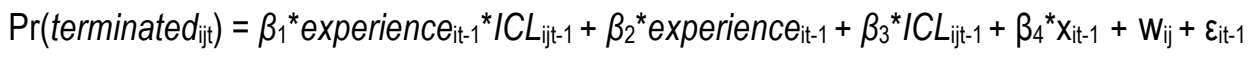

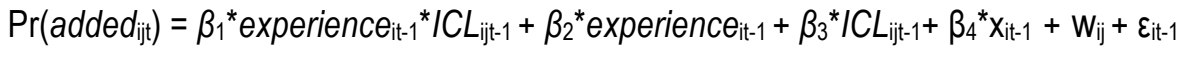


Here, $x_{\mathrm{it}-1}$ is a set of observed covariates, $\mathrm{w}_{\mathrm{ij}}$ is a set of unobserved attributes of the firmpartner dyad, and $\varepsilon_{\mathrm{it}-1}$ is a random error. Because our research question focuses on how risks within pairs of firms change over time, we specify a fixed effect for each unique dyad and estimate the parameters through a fixed-effects logit with standard errors clustered by dyad (Chamberlain, 1982; Greene, 2008). This stringent approach exploits within-dyad variance and rules out any endogenous, time invariant attribute of each dyad and firm $\left(\mathrm{w}_{\mathrm{ij}}\right)$ - which matters because each partnership has a unique relational profile (e.g. Dyer \& Singh, 1998). The probability of terminating or adding a tie between pairs of firms is a function of how our variables of interest and the controls change over time. One disadvantage of this specification is that dyads that do not experience a termination or addition cannot be included in the analysis. We compared the fixed effects model to a random effects alternative (in which no data is dropped) and the Hausman test strongly favored the fixed effects option $(p<0.001)$. We interpret the coefficients as applying only to dyads that exhibit an observed change, so that we are assessing the treatment effect on the 'treated' (Angrist \& Pischke, 2008).

Closure: This variable operates at the firm (ego network) level, and the equation of interest is as follows:

$$
\text { Closure }_{\mathrm{i}, \mathrm{t}}=\beta_{1}{ }^{*} \text { experience }_{\mathrm{it}-1}{ }^{*} I C L_{\mathrm{it}-1}+\beta_{2}{ }^{*} \text { experience }_{\mathrm{it}-1}+\beta_{3}{ }^{*} I C L_{\mathrm{it}-1}+\beta_{4}{ }^{*} \text { closure }_{\mathrm{it}-1}+\beta_{5}{ }^{*} \mathrm{X}_{\mathrm{it}-1}+\mathrm{v}_{\mathrm{i}}+\varepsilon_{\mathrm{it}-1}
$$

Once again, $x_{\mathrm{it}-1}$ is a matrix of observed control variables and $\varepsilon_{\mathrm{it}-1}$ is a random error. A few features of this equation require consideration. First, $v_{\mathrm{i}}$ is part of the error and captures any unobserved, time-invariant firm characteristic. If correlated with the independent variables, these unobserved factors produce inconsistent estimates (Wooldridge, 2002). Second, the introduction of a lagged dependent variable ( closure $\left._{\mathrm{it}-1}\right)$ is necessary to account for structural inertia but it also creates problems by being correlated with the random error $\varepsilon_{\mathrm{it}-1 .}{ }^{5}$ Third, $I C L$ and its interaction with experience may be endogenous because unobservables dynamically affecting structure may be related to the level of indirect competitor links. We face the complexity of having to address

\footnotetext{
${ }^{5}$ This occurs because $y_{\mathrm{it}}=\beta_{0}+\beta_{1} * y_{\mathrm{i}, \mathrm{t}-1}+\beta_{2} * x_{\mathrm{i}, \mathrm{t}-1}+v_{\mathrm{i}}+\varepsilon_{\mathrm{i}, \mathrm{t}-1}$, and $\varepsilon_{\mathrm{i}, \mathrm{t}-1}$ is serially correlated to $\varepsilon_{\mathrm{it}}$ in the original equation, violating the strict exogeneity assumption of traditional panel estimators (see Wooldridge, 2002: 252-256).
} 
all three of the issues raised in this paragraph simultaneously-unobserved heterogeneity, an endogenous lagged dependent variable, and possibly endogenous regressors.

To do so, we adopt a system GMM dynamic panel estimator (Arellano \& Bover, 1995; Arellano \& Bond, 1991; Blundell \& Bond, 1998). This provides a two-pronged solution to the concerns just raised. Consider the generic equation: $y_{\mathrm{i}, \mathrm{t}}=\beta_{0}+\beta_{1} * y_{\mathrm{it}-1}+\beta_{2}{ }^{*} z_{\mathrm{it}-1}+\beta_{3} * x_{\mathrm{it}-1}+v_{\mathrm{i}}+\varepsilon_{\mathrm{it}-}$ 1. Here, $y_{\mathrm{i}, \mathrm{t}}$ is the dependent variable, $y_{\mathrm{it}-1}$ represents the lagged dependent variable, $z_{\mathrm{it}-1}$ is a matrix of endogenous independent variables, and $x_{\mathrm{it}-1}$ is a matrix of exogenous covariates (the other parameters are as already described). The first step is to take the first-difference of each variable, resulting in the following 'differenced' equation: $\Delta y_{\mathrm{i}, \mathrm{t}}=\beta_{0}+\beta_{1} * \Delta y_{\mathrm{it}-1}+\beta_{2} * \Delta z_{\mathrm{it}-1}+$ $\beta_{3} * \Delta x_{\mathrm{it}-1}+\Delta \varepsilon_{\mathrm{it}-1}$. This differenced equation eliminates $v_{\mathrm{i}}$, thus getting rid of unobserved fixed effects. However, $\Delta y_{\mathrm{it}-1}\left(=y_{\mathrm{it}-1}-y_{\mathrm{i}, \mathrm{t}-2}\right)$ is still endogenous because $\Delta \varepsilon_{\mathrm{it}-1}=\varepsilon_{\mathrm{it}-1}-\varepsilon_{\mathrm{i}, \mathrm{t}-2}$ and the term $\varepsilon_{\mathrm{i}, \mathrm{t}-2}$ is correlated with $y_{\mathrm{i}, \mathrm{t}-2}$. To solve this problem, the estimator uses older differenced lags of the dependent variable as instruments for $\Delta y_{\mathrm{it}-1}$. Thus, for example, $\Delta y_{\mathrm{i}, \mathrm{t}-2}, \Delta y_{\mathrm{i}, \mathrm{t}-3}, \ldots, \Delta y_{\mathrm{i}, \mathrm{t}-\mathrm{T}}$ can be used as instruments for $\Delta y_{\text {it-1. }}$. As long as the serial correlation between $\Delta y_{\text {it-1 }}$ and $\Delta \varepsilon_{\text {it-1 }}$ goes beyond no more than one period, the estimates are consistent. Similarly, the endogeneity of $\Delta z_{\text {it- } 1}$ (e.g. indirect links to competitors) is addressed by utilizing a set of lagged values of $\Delta z_{\mathrm{it}-1}\left(\Delta z_{\mathrm{i}, \mathrm{t}-2}\right.$, $\Delta z_{\mathrm{i}, \mathrm{t}-3}, \Delta z_{\mathrm{it}-4}$, etc.) as instruments. While this model may not have the virtue of including theoretically substantive instruments for the endogenous covariates (as in 2SLS), it does allow us to address multiple endogeneity concerns by exploiting the basic idea that autocorrelation decreases with differenced lags of any given variable. We used the maximum possible $T_{i}-p-2$ lags (in our case $14-1-2=11$ ), where $T_{i}$ is the number of years in the panel and $p$ is the number of lagged DV's included in the equation.

\section{Control Variables}

The controls listed in this section are included in all models unless otherwise noted. When a similar variable is included as a characteristic of a firm's (actual or potential) partner at the dyadic level and as an attribute of the firm's ego network, the measure at the ego network level is averaged across all the focal firm's partners. For example, we control for the profitability 
of a partner at the dyad level while in the closure model we control for the average profitability of all partners in the focal firm's ego network. We also note that, since changes in composition and structure depend on the incentives, actions, and behaviors of the focal firm and its partner(s), most of the controls described are included for both sides of the relationship.

Dyadic safeguards: We claim that the safeguards firms adopt to protect from direct partners' opportunism are insufficient to protect from the risks of indirect ties to rivals, so accounting for these is essential. We discussed legal, social, and strategic defenses in the literature review. In board interlocks, protections are provided by law, contracts, and corporate governance codes, typically including confidentiality clauses, statements of fiduciary responsibility, and conditions that can trigger prosecution or the termination of the relationship (Aguilera, 2005). As the same laws and codes govern all firms in the sample, legal defenses are implicitly accounted for by the common setting. (Below we discuss mutual ownership as a legal mechanism common in the German context.) Some of the strategic defenses discussed in prior work on startups do not apply to board networks, but geographic colocation (e.g. Hallen et al. 2013) and other unobservables are accounted for by the dyad fixed effect in our analysis.

We control for two social safeguards considered in prior research. First, trust and loyalty are often proxied by the history of prior ties among firms (e.g. Gulati, 1995). Since we are concerned about the risks posed by indirectly linked rivals, a partner with ties to a focal firm's competitors might face pressure from these firms to choose between the focal firm and them in terms of relative trust and loyalty. To get at this, we control for relative history, which captures the difference between the number of years the focal firm and the (actual or potential) partner have been connected and the average number of years the (actual or potential) partner and ego's competitors have been connected. The more positive this variable, the greater the trust the partner should have in the focal firm; the more negative, the greater the trust in the focal firm's competitors. Second, recent work has demonstrated that centrality can be a social protection because status or influence discourage third parties from behaving opportunistically for fear of social punishment (Hallen et al., 2013; Polidoro et al., 2011). We thus include the degree 
centrality of the firm's (actual or potential) partners and of the focal firm in all models.

Centrality is correlated at high levels with other covariates in the closure models, but the results are robust whether it is included or not.

Events other than the opening of Eastern Europe: We control for three events during the period of our study that affected board composition in Germany. The first two impacted the governance system. The traditional pattern of equity ownership among German firms weakened throughout the 1990's. These cross-holdings were historically an important means of legal protection and control, so its decline may have influenced the pattern of board ties during our study period (Kogut \& Walker, 2001). We thus included controls for equity owned by other firms and for the equity owned in other firms by both the focal firm and its partners, updated yearly. The former is measured as the percentage of a firm's equity owned by other firms in the sample, and the latter captures the average equity owned by a firm in other firms within the sample. In addition, the period saw a strong change in emphasis toward a shareholder logic of corporate control (Fiss \& Zajac, 2004). One of the clearest manifestations of this diffusion was the adoption of stock options, which was influenced by patterns of board networks (Sanders \& Tuschke, 2007). We thus control for stock option experience, coded as 1 if a firm had adopted stock option compensation and zero otherwise. This measure was excluded as an attribute of the firm's partners in the closure network analysis because it created multicollinearity problems. The third event was the occurrence of an acquisition wave (Marin, 2011), representing a strategic issue other than the opening of Eastern Europe about which board interlocks provided knowledge. We thus control for the acquisition experience of the focal firm and its partners, measured as the logged number of acquisitions that the firm completed in the previous five years.

Motivations of individual directors: We included variables affecting director's incentives and constraints to serve on boards. We added firm performance for both the focal and partner firm because directors are motivated by the prestige of serving in highly successful organization (Boivie, Graffin, \& Pollock, 2012). (Successful organizations may also have greater latitude to add and drop ties and influence their network structures.) Directors with significant 
additional time commitments are more likely to leave a board and less likely to accept new appointments. To capture this, we adapted two measures from Boivie et al. (2012). First, the number of CEOs on firms' boards is relevant because CEOs have highly demanding jobs. Second, we proxied for the busyness of directors on a firms' board as the ratio of external board appointments held by all directors divided by the size of the board.

Motivations of other firms: The actions of the focal firm's direct partners or those of its indirectly linked competitors affect the dynamics of tie additions, deletions, and closure. In addition to controlling for trust, which we already described, we added several covariates. Just as the number of indirect links to competitors created by a firm's partner increases the risk of unwanted leakage for the focal firm, the same is true of the indirect links generated by the focal firm for its partner. We thus controlled for indirect competitor links created by the focal firm. This control was not included in the ego-level analysis because its average across all partners is highly correlated to other covariates, though the closure results are robust to its inclusion. Since investing in Eastern Europe during this period was highly risky, it could be that partners sought to disassociate from focal firms that increasingly invested in the region because such actions were not legitimated. This would partially depend on the partner's own experience with Eastern Europe, so we controlled for partner experience. This control is also important because, inasmuch as the partner has similar protective motivations to the focal firm as it accumulates experience, the focal firm's network may change as a result.

If interlocked firms develop similar experiences their knowledge will overlap and the focal firm or its partners may seek new ties for fresh ideas (Nakamura, Shaver, \& Yeung, 1996). Overlap in investment choices might also signal increasing competition among partners. We thus controlled for the difference in the number of countries entered by the focal firm relative to its interlocked firms, Eastern European (EE) experience difference. We noted above that $4 \%$ of ties are between firms in the same 6-digit GICS code. In the dyadic analyses, this is accounted for through the dyad-level fixed effect. In the ego-level analysis, we accounted for this by including the percentage of same industry partners in the focal firm's ego network. We also added a 
measure of foreign sales, the firm's ratio of international to total sales, because general international experience may also influence the firm's and its partner's network opportunities given our focus on foreign market knowledge. ${ }^{6}$ Of all the control variables listed in this section, four are also included in the study by Tuschke et al. (2014): firm profitability, foreign sales, focal firm degree centrality ('aggregated ties' in the other study), and CEOs on the board (measured separately by 'outgoing' and 'incoming' ties in the other study).

\section{RESULTS}

Tables $1 \mathrm{a}$ and $1 \mathrm{~b}$ contain descriptive statistics and correlations for the dyad and ego samples, respectively. Because some correlations exceed 0.50 , we tested for multicollinearity and the VIF scores were below problematic levels. Tables 2 and 3 present the results for tie terminations and additions, respectively. Models 1 and 6 include only the controls. In models 2 and 7 we added the main effects of the variables of interest. Per the baseline expectation, firms that accumulated Eastern European experience became more likely to terminate an interlock with another firm $(\mathrm{p}<0.10)$ and to form a tie with a new firm $(\mathrm{p}<0.01)$. Model 2 reports that as indirect competitor links increased, the odds of termination increased $(p<0.05)$. Model 7 shows a symmetric effect on additions because the negative coefficient means that lower numbers of indirect links to competitors encouraged tie formation ( $\mathrm{p}<0.01$ ). This supports H1a and H1b.

Insert Tables 1a, 1b, 2, and 3 Here

Models 3-5 and 8-10 provide support for $\mathrm{H} 2 \mathrm{a}$ and $\mathrm{H} 2 \mathrm{~b}$. In Model 3 we report a positive and significant interaction of firm experience with indirect competitor links on tie termination (p $<0.01)$. Because the sign and significance of interaction coefficients in non-linear models might be inaccurate (Ai \& Norton, 2003), we split the sample at the mean level of indirect competitor links and compared effects across subsamples (Shaver, 2007) in Models 4-5. The contrast is strongly indicative of a positive moderating effect because experience had a negative effect on

\footnotetext{
${ }^{6} \mathrm{We}$ did not control for firm size because in Germany size is highly correlated with degree centrality. The law dictates that the number of directors should be a function of the number of employees - and larger boards mathematically have greater numbers of ties. However, in robustness checks, we included firm size in our analysis — on its own and with degree centrality — and the results remained unchanged.
} 
termination for firms with low indirect competitor links $(\mathrm{p}<0.01)$ and a positive effect for firms with high levels of such links $(\mathrm{p}<0.01)$. In terms of tie additions, the interaction coefficient is negative in Model 8 of Table $3(\mathrm{p}<0.01)$, and the subsample comparison is consistent with such a negative interaction in Models 9-10 - a positive effect of experience for the low indirect link subsample $(\mathrm{p}<0.01)$ and a negative effect for the high indirect link subsample $(\mathrm{p}<0.10)$. We graphed the joint effects of experience and indirect competitor links in Figures 2a and $2 \mathrm{~b}$ based on the estimated coefficients in Models 3 and 8, respectively. ${ }^{7}$

Insert Figures $2 \mathrm{a}$ and $2 \mathrm{~b}$ Here

Table 4 contains the results for network closure. Model 11 includes only the control variables. The lagged dependent variable was highly significant, confirming the importance of structural inertia as an explanation for the evolution of network structure. The remaining models add our variables of interest in stepwise fashion. We found support for H3 because the interaction of experience in Eastern Europe with indirect competitor links was positive and significant $(\mathrm{p}<0.05)$ in model 13. This effect is graphed in Figure 3.

Insert Table 4 and Figure 3 Here

\section{Robustness Tests and Mechanism Checks}

We have argued that dyadic protections are insufficient safeguards against the spillover risks of indirect ties to rivals. While the results so far control for dyadic protections, we probed further into whether our proxy for trust, relative history, was effective in diminishing the risks of leakage through indirect ties. We interacted relative history with indirect competitor links and found no effect on tie termination, though the main effect of indirect competitor links remained significant $(\mathrm{p}<0.05)$. For tie additions, the interaction of relative history with indirect competitor links did weaken $(\mathrm{p}<0.05)$ but not eliminate the negative main effect of indirect links to rivals on tie formation. Moreover, the interaction of relative history with indirect

\footnotetext{
${ }^{7}$ We graphed the linear prediction because there is no clear way of calculating average predicted probabilities for the entire sample in fixed effects logit models (see Greene, 2008). The numbers in the vertical axis do not have a straightforward interpretation, but the graph accurately shows the interaction effect.
} 
competitor links had no effect on network closure. In another specification, including the interaction of relative history with EE experience did not change the sign or significance of the interaction between EE experience and indirect competitor links for tie terminations (H2a), tie additions (H2b), or network closure (H3). These findings lend credence to our core idea that the risks posed by indirectly tied rivals are difficult to overcome through dyadic safeguards.

An alternative explanation for the findings regarding tie terminations could be that partners seek to disassociate themselves from a focal firm investing in Eastern Europe if this strategy is seen as risky and illegitimate. This would particularly be the case for partners with other links to the focal firm's industry because the pressure to 'drop' the focal firm may come from the focal firm's rivals and because the focal firm's partner has a functionally equivalent replacement if it drops the focal firm. We thus ran our models with an additional control for the experience in Eastern Europe of indirectly linked competitors, reasoning that this alternative explanation depends on whether the focal firm's competitors are also engaging in Eastern European investment. The results reported above are strongly robust to this additional control.

We mentioned that we chose the measure of experience from seven possible candidates. The results concerning tie additions and terminations $(\mathrm{H} 1-\mathrm{H} 2)$ remain nearly identical regardless of which measure we use. The effects on closure (H3) are supported at $p<0.10$ or less for all cases except when using the non-logged measure of 'organizational forgetting.' This indicates a reasonably strong robustness given the many different theories of how experience relates to knowledge. While most firms in the sample can be clearly categorized into a single GICS code (e.g. Allianz clearly belongs in insurance), five firms could be considered highly diversified per the Forbes list of worldwide conglomerates and may have competitors in multiple industries. We excluded them from the sample and found nearly identical results for all the hypotheses.

\section{DISCUSSION}

The tension between cooperative knowledge sharing and the unwanted leakage of that knowledge is salient in interorganizational ties. Scholarly interest in this dilemma has centered on sources of this problem at the locus of the dyad and solutions designed to help direct partners 
behave constructively. Social networks research—which emphasizes extra-dyadic processeshas tended to focus on the positive aspects of broader structures (e.g. learning, innovation, performance) and, relatively speaking, overlooked the risks of knowledge spillover to indirectly linked competitors. The study by Cox-Pahnke et al. (2014), which was developed concurrently with ours, shows that indirect ties to rivals undermine innovation — reinforcing the importance of adopting protections designed to mitigate their unique threats. These extra-dyadic risks require solutions that go beyond those considered by work focused on knowledge leakage to direct partners. Our central contribution is to introduce second order links to rivals as a source of leakage risk and demonstrate that firms pursue pruning, grafting, and closing as defensive mechanisms to protect their strategic knowledge from this novel source of risk-even when dyadic safeguards are in place.

Our work speaks most directly to studies on various defenses to mitigate risks of knowledge spillover from network partners. Recent papers on the 'sharks' dilemma have made important advances by showing that strategic and social considerations are crucial at the time of tie formation (e.g. Katila et al. 2008; Diestre \& Rajagopalan, 2012). Hallen et al. (2013) and Polidoro et al. (2011) discuss how extra-dyadic properties such as centrality and structural embeddedness can be effective safeguards by encouraging tie formation or preventing tie dissolution, though in these papers the immediate partner is the source of the risk and the target of the safeguard. The risk posed by second degree ties would be relatively inconsequential if solutions directed at first degree partners were also effective in preventing leakage to indirectly linked rivals. We argued why such solutions are unlikely to be sufficient and which additional safeguards - i.e., pruning, grafting, and closing the network - the firm may use.

Interestingly, the additional tests reported in the robustness section reveal that a powerful dyadic safeguard like trust does little to change the tendency of firms to prune, graft, and close their networks to protect their knowledge from leaking to competitors. This is intriguing because it suggests a boundary condition to the virtues of relational embeddedness (e.g. Dyer \& Singh, 1998). A natural question is why a firm might deem a trusted partner insufficiently reliable to 
protect its knowledge and sever or avoid the tie or close its network. We argued that the risk of indirect leakage might be too complex to deal with only through behavioral solutions. It might also be that trust itself is strained when a current partner increasingly begins forming ties with rivals. The data did not allow us to explore this further, but we see this as an interesting issue to be studied more carefully. We emphasize that we do not see trust or other dyadic safeguards as unimportant. Rather, we think it is useful for research to better understand the conditions under which specific safeguards are effective or ineffective.

While the risks of indirect links to rivals exist in other networks, in board settings firms are either legally constrained or highly unlikely to establish direct ties to rivals. In alliances, in contrast, firms establish both direct and indirect ties to rivals (e.g. Hamel, 1991). An interesting study would assess the different risks of direct and indirect links to rivals as well as the defenses that are effective for each kind of risk. Of course, we only looked at second-degree paths to rivals, and further work should consider how different path lengths and affect protective actions in knowledge networks. Indirect links may also have strategic benefits as sources of intelligence regarding rivals. Our focus was on the conditions that create more costs than benefits, triggered by the accumulation of high levels of strategic knowledge. It may be interesting to more explicitly model inflows and outflows of competitive knowledge to understand when preserving vs. dropping such linkages is warranted.

As mentioned earlier, networks research has for long emphasized the relevance of extradyadic relationships with constructs like triads, centrality, structural holes, closure, or structural embeddedness. This work has produced tremendous insights on the positive consequences of social structure, but it has tended to overlook the identity of the nodes indirectly linked throughout the broader structure. The implicit assumption has been that, given two nodes with identical positions, resources will flow to them in the same way despite nodal attributes. Burt's (2010) work on secondhand brokerage and closure seeks to question some of these benefits, but even in those studies the emphasis is on the lack of upsides instead of explicit downsides. We have specifically identified second-order nodes as rivals or non-rivals and demonstrated how 
firms seek to prevent knowledge flows to rivals, so that nodal attributes interact with structure (e.g. Cowan \& Jonard, 2009). Rivalry is important as an attribute because it brings up competition in networks and encourages researchers to consider how certain structures can have negative outcomes if they enable undesirable resource flows.

Relatedly, our focus on knowledge derived from experience is also relevant for research on organizational learning. The literature on experiential learning has emphasized the value of experience in a knowledge domain for application to future related decisions (Argote, 1999). Yet we argue that knowledge also has value as a network resource prized by others and show that its accumulation creates risks of leakage to rivals through the network. This is consequential because it means that the different rates at which firms develop experience with valuable strategies may help explain changes in their network composition and structure. At the same time, one firm's experiential learning is the source of vicarious learning for another firm. Our findings imply that competitive considerations may undermine the process of vicarious learning when indirect links to rivals are involved-particularly for firms that generate such indirect ties. Moreover, firms that possess the knowledge may seek to block rivals from the opportunity to learn vicariously. Thus, competition is an important consideration in determining how quickly and from whom firms learn in networks (e.g. Ingram \& Baum, 1997).

The safeguards of pruning, grafting, and closing imply a degree of influence over network composition and structure - and thus are highly relevant for the network dynamics literature. Pruning and grafting are about terminating and avoiding risky ties, and tie additions and terminations are the building blocks of network change. We are able to explain which ties get added and dropped not because of joint value creation or the lack thereof, but rather because of the downside risk of knowledge spillover to a rival. In terms of structural change, we provide an important explanation for the evolution of network structure towards closure. Burt (2002) points out the velocity with which bridging positions in networks seem to disappear and other scholars have wondered why, if structural holes provide so many advantages, they are not 'closed' more rapidly by alters seeking to undermine the firm's brokerage advantage (e.g. 
Salancik, 1995). Such explanations of closure focus on the motivations of partners who seek to undermine the advantage of the ego. Our results provide a different explanation: the broker itself has a defensive, competitive motivation to close its network. This may cause a loss of brokerage advantages (Ryall \& Sorenson, 2007) but is compensated by the increased safety of strategic knowledge, though firms probably have less control over closure than over pruning and grafting.

At a broader level, this study helps provide a more balanced picture of the upsides and downsides of networks. Accounts of network evolution, for example, tend to focus on cooperative or 'positive' motivations to explain network composition and structure. While calls have been made to better understand how competition and other risks in networks affect network change (Ahuja, Soda, \& Zaheer, 2012; Gulati, 2007), empirical work in this area is still sparse and focuses on the negative content of the tie itself (e.g. Sytch \& Tartarynowicz, 2013) rather than on the presence and location of the firms rivals in the network. We believe our paper adds value in this regard and resonates with Lin's notion that resource protection is a fundamental imperative in networks and that "only when the existing valued resources are secured do [network] actors seek to gain additional valued resources." (2001: 32-33)

\section{Limitations and Future Research Possibilities}

We do not directly observe firms' motives for dissolving and establishing board ties or for closing their networks, nor do we measure the strength and variety of knowledge that firms exchange through ties. While the interviews we conducted validated some of the mechanisms we propose, ultimately we cannot causally prove that the protection of knowledge drives the results. Our focus was on board interlocks regardless of how they are formed, but it would be interesting to assess whether interlocks originating from the management board differ in terms of leakage risk and influence on pruning and closing from those generated by the supervisory board. We were unable to include certain relevant variables in the empirical analysis. For instance, heterogeneity in the mode and size of investment into Eastern Europe may affect the perceived threat of knowledge spillover but we cannot explore that possibility. We also lacked data on 
exogenous shocks that create vacancy chains and impact changes in the board network (Lusher, Koskinen, \& Robins, 2012), such as the untimely death or retirement of a director.

We have projected a two-mode board interlock network (composed of individuals and firms) onto a single-mode network of interfirm ties. Recent studies have begun pointing out biases in measures of closure when projecting from the 'event' (i.e. firm) to the 'individual' (i.e. director) network (Opsahl, 2013; Piepenbrink \& Gaur, 2013). There is little guidance on the prevalence of this problem when projecting from the individual to the firm network, as we do, so our measures should be considered with some caution until further research on this issue comes to light. Also, while the dynamic panel estimator addresses multiple sources of endogeneity simultaneously, it is not equipped to include theoretically derived instruments for endogenous regressors. Relatedly, the necessary use of robust standard errors in the models of network closure prevented us from conducting the Sargan test of overidentification (Arellano \& Bond, 1991). Yet the dynamic panel estimator provides a reasonable set of benefits despite these tradeoffs. Finally, the choice to focus on within-dyad variance in the analyses of terminations and additions requires caution in interpreting the coefficients as applying to effects over time for dyads that experience a change. Results might differ in an analysis including dyads that never form or dissolve, though unobserved heterogeneity would be a concern in such models.

Conclusion. We explored how firms protect themselves against the risks of an unwanted leakage of strategic knowledge to indirectly linked competitors. We argued that safeguards directed at preventing opportunistic behavior by directly linked firms in a dyad are not sufficient to overcome extra-dyadic risks of knowledge spillover. Instead, firms attempt to manage the composition and structure of their network through pruning, grafting, and closing. These safeguards become increasingly important as firms accumulate strategic knowledge and as their partners generate more indirect ties to competitors. We found support for our theorizing in a longitudinal study of changes in the network of German board interlocks during 1990-2003. 


\section{REFERENCES}

Ahuja, G. 2000. Collaboration Networks, Structural Holes, and Innovation: A Longitudinal Study. Administrative Science Quarterly, 45(3): 425-455.

Ahuja, G. 2000. The Duality of Collaboration: Inducements and Opportunities in the Formation of Interfirm Linkages. Strategic Management Journal, 21(3): 317-343.

Ahuja, G., Soda, G., \& Zaheer, A. 2012. Introduction to the Special Issue: The Genesis and Dynamics of Organizational Networks. Organization Science, 23(2): 434-448.

Ai, C., \& Norton, E. C. 2003. Interaction terms in logit and probit models. Economics Letters, 80(1): 123-129.

Amburgey, T. L., \& Miner, A. S. 1992. Strategic Momentum: the Effects of Repetitive, Positional, and Contextual Momentum on Merger Activity. Strategic Management Journal, 13(5): 335-348.

Angrist, J. D., \& Pischke, J.-S. 2008. Mostly harmless econometrics: An empiricist's companion. Princeton, NJ: Princeton University Press.

Arellano, M., \& Bond, S. 1991. Some Tests of Specification for Panel Data: Monte Carlo Evidence and an Application to Employment Equations. Review of Economic Studies, 58(194): 277-297.

Arellano, M., \& Bover, O. 1995. Another look at the instrumental variable estimation of errorcomponents models. Journal of Econometrics, 68(1): 29-51.

Argote, L. 1999. Organizational learning: Creating, retaining, and transferring knowledge. New York: Kluwer Academic Publishers.

Argote, L., \& Miron-Spektor, E. 2011. Organizational learning: From experience to knowledge. Organization Science, 22(5): 1123-1137.

Baker, W. E. 1990. Market networks and corporate behavior. American journal of sociology, 589-625.

Beckman, C. M., \& Haunschild, P. R. 2002. Network Learning: The Effects of Partners' Heterogeneity of Experience on Corporate Acquisitions. Administrative Science Quarterly, 47(1): 92-124.

Bell, G. G., \& Zaheer, A. 2007. Geography, networks, and knowledge flow. Organization Science, 18(6): 955-972.

Blundell, R., \& Bond, S. 1998. Initial conditions and moment restrictions in dynamic panel data models. Journal of Econometrics, 87(1): 115-143.

Boivie, S., Graffin, S. D., \& Pollock, T. G. 2012. Time for me to fly: predicting director exit at large firms. Academy of Management Journal, 55(6): 1334-1359.

Burt, R. S. 1992. Structural holes: The social structure of competition. Cambridge, MA: Harvard University Press.

Burt, R. S. 2002. Bridge decay. Social Networks, 24(4): 333-363.

Burt, R. S. 2005. Brokerage and Closure: An Introduction to Social Capital: An Introduction to Social Capital. Oxford University Press.

Burt, R. S. 2010. Neighbor networks: Competitive advantage local and personal. New York: Oxford University Press.

Carter, C. B., \& Lorsch, J. W. 2004. Back to the drawing board: Designing corporate boards for a complex world. Cambridge, MA: Harvard Business School Press.

Chamberlain, G. 1982. Analysis of covariance with qualitative data. Cambridge, MA: National Bureau of Economic Research.

Coleman, J. S. 1988. Social Capital in the Creation of Human Capital. American Journal of Sociology, 94(S1): S95-S120. 
Cowan, R., \& Jonard, N. 2009. Knowledge portfolios and the organization of innovation networks. Academy of Management Review, 34(2): 320-342.

Cox-Pahnke, E., McDonald, R., Wang, D., \& Hallen, B. 2014. The liability of leakage: Indirect ties, intermediaries, and innovation. Academy of Management Journal, forthcoming.

Daft, R. L., \& Lengel, R. H. 1986. Organizational information requirements, media richness and structural design. Management Science, 32(5): 554-571.

Davis, G. F., \& Greve, H. R. 1997. Corporate elite networks and governance changes in the 1980s. American Journal of Sociology, 103(1): 1-37.

Davis, G. F., \& Mizruchi, M. S. 1999. The money center cannot hold: Commercial banks in the US system of corporate governance. Administrative Science Quarterly, 44(2): 215-239.

De Holan, P. M., \& Phillips, N. 2004. Remembrance of things past? The dynamics of organizational forgetting. Management Science, 50(11): 1603-1613.

Der Spiegel. 1997, April 7. Sprecher ohne Mandat, 15.

Diestre, L., \& Rajagopalan, N. 2012. Are all "sharks" dangerous? new biotechnology ventures and partner selection in R\&D alliances. Strategic Management Journal, 33(10): 11151134.

Dushnitsky, G., \& Shaver, J. M. 2009. Limitations to interorganizational knowledge acquisition: the paradox of corporate venture capital. Strategic Management Journal, 30(10): 10451064.

Fiss, P. C., \& Zajac, E. J. 2004. The diffusion of ideas over contested terrain: The (non) adoption of a shareholder value orientation among German firms. Administrative Science Quarterly, 49(4): 501-534.

Flaig, I. 2006. Zulieferer unterschätzen Risiko der Verlagerung. Stuttgarter Nachrichten, 9.

Gimeno, J. 2004. Competition within and between networks: The contingent effect of competitive embeddedness on alliance formation. Academy of Management Journal, 47(6): 820-842.

Granovetter, M. 1992. Problems of explanation in economic sociology. In N. Nohria and R. Eccles (Eds. ) Networks and Organizations: Structure, Form, and Action: 25-56. Boston: Harvard Business School Press.

Granovetter, M. S. 1973. The Strength of Weak Ties. American Journal of Sociology, 78(6): 1360.

Grant, R. M. 1996. Toward a knowledge-based theory of the firm. Strategic management journal, 17: 109-122.

Greene, H. W. 2008. Econometric Analysis. New Jersey: Prentice-Hall.

Gulati, R. 1995. Social Structure and Alliance Formation Patterns: A Longitudinal Analysis. Administrative Science Quarterly, 40(4): 619-652.

Gulati, R. 2007. Managing network resources: alliances, affiliations, and other relational assets. New York: Oxford University Press.

Gulati, R., \& Gargiulo, M. 1999. Where do interorganizational networks come from? American Journal of Sociology, 104(5): 1398-1438.

Hallen, B., Katila, R., \& Rosenberger, J. 2013. Unpacking Social Defenses: A ResourceDependence Lens on Technology Ventures, Venture Capital, and Corporate Relationships. Academy of Management Journal, forthcoming.

Hamel, G. 1991. Competition for competence and inter-partner learning within international strategic alliances. Strategic management journal, 12: 83-103.

Hatch, N. W., \& Dyer, J. H. 2004. Human capital and learning as a source of sustainable competitive advantage. Strategic management journal, 25(12): 1155-1178. 
Haunschild, P. R. 1994. How Much Is That Company Worth?: Interorganizational Relationships, Uncertainty, and Acquisition Premiums. Administrative Science Quarterly, 39(3): 391411.

Iankova, E. A. 2002. Eastern European capitalism in the making. Cambridge, UK: Cambridge University Press.

Jürgens, U., Naumann, K., \& Rupp, J. 2000. Shareholder value in an adverse environment: the German case. Economy \& Society, 29(1): 54-79.

Katila, R., Rosenberger, J. D., \& Eisenhardt, K. M. 2008. Swimming with Sharks: Technology Ventures, Defense Mechanisms and Corporate Relationships. Administrative Science Quarterly, 53(2): 295-332.

Khanna, T., Gulati, R., \& Nohria, N. 1998. The dynamics of learning alliances: competition, cooperation, and relative scope. Strategic Management Journal, 19(3): 193-210.

Kogut, B., \& Walker, G. 2001. The Small World of Germany and the Durability of National Networks. American Sociological Review, 66(3): 317-335.

Kogut, B., \& Zander, U. 1992. Knowledge of the firm, combinative capabilities, and the replication of knowledge. Organization Science, 3(3): 383-397.

Koskinen, J., \& Edling, C. 2012. Modelling the evolution of a bipartite network-Peer referral in interlocking directorates. Social Networks, 34(3): 309-322.

Levitt, B., \& March, J. G. 1988. Organizational Learning. Annual Review of Sociology, 14(1): 319-340.

Lin, N. 2001. Social Capital: A Theory of Social Structure and Action. Cambridge, UK: Cambridge University Press.

Lusher, D., Koskinen, J., \& Robins, G. 2012. Exponential Random Graph Models for Social Networks: Theory, Methods, and Applications. Cambridge, UK: Cambridge University Press.

Marin, D. 2011. The opening up of Eastern Europe at 20: jobs, skills and reverse maquiladoras in Austria and Germany, in Jovanovic, M. N. (ed.) International Handbook on the Economics of Integration: Competition, Spatial Location of Economic Activity and Financial Issues: 296-323.

Mayer, K. J., \& Salomon, R. M. 2006. Capabilities, contractual hazards, and governance: Integrating resource-based and transaction cost perspectives. Academy of Management Journal, 49(5): 942-959.

McDonald, M. L., \& Westphal, J. D. 2010. A Little Help Here? Board Control, CEO Identification with the Corporate Elite, and Strategic Help Provided to CEOs at Other Firms. Academy of Management Journal, 53(2): 343-370.

Mizruchi, M. S. 1996. What Do Interlocks Do? An Analysis, Critique, and Assessment of Research on Interlocking Directorates. Annual Review of Sociology, 22(1): 271-298.

Morgan Stanley. 2010. Notice of 2010 Annual Meeting of Shareholders. Morgan Stanley. Murray, A. 2006, September 6. Directors Cut: H-P Board Clash Over Leaks Triggers Angry Resignation. Wall Street Journal, 1.

Nakamura, M., Shaver, J. M., \& Yeung, B. 1996. An empirical investigation of joint venture dynamics: Evidence from US-Japan joint ventures. International Journal of Industrial Organization, 14(4): 521-541.

Nelson, R. R., \& Winter, S. G. 1982. An Evolutionary Theory of Economic Change. Cambridge, MA: Harvard University Press.

Opsahl, T. 2013. Triadic closure in two-mode networks: Redefining the global and local clustering coefficients. Social Networks, 35(2): 159-167. 
Orenstein, M. A. 2001. Out of the red: Building capitalism and democracy in postcommunist Europe. Ann Arbor, MI: University of Michigan Press.

Oxley, J. E., \& Sampson, R. C. 2004. The scope and governance of international R\&D alliances. Strategic Management Journal, 25(8-9): 723-749.

Palmer, D. A., Jennings, P. D., \& Zhou, X. 1993. Late Adoption of the Multidivisional Form by Large U.S. Corporations: Institutional, Political, and Economic Accounts. Administrative Science Quarterly, 38(1): 100-131.

Piepenbrink, A., \& Gaur, A. S. 2013. Methodological Advances in the Analysis of Bipartite Networks An Illustration Using Board Interlocks in Indian Firms. Organizational Research Methods, 16(3): 474-496.

Podolny, J. M. 2001. Networks as the Pipes and Prisms of the Market. American Journal of Sociology, 107(1): 33-60.

Polidoro, F., Ahuja, G., \& Mitchell, W. 2011. When the Social Structure Overshadows Competitive Incentives: The Effects of Network Embeddedness on Joint Venture Dissolution. Academy of Management Journal, 54(1): 203-223.

Prochnow, E. 2004. Ein Engagement in Ousteuropa birgt manches Risiko. Impulse, 5: 44.

Rosenkopf, L., \& Almeida, P. 2003. Overcoming local search through alliances and mobility. Management Science, 49(6): 751-766.

Ryall, M. D., \& Sorenson, O. 2007. Brokers and competitive advantage. Management Science, 53(4): 566-583.

Salancik, G. R. 1995. Wanted: A Good Network Theory of Organization. Administrative Science Quarterly, 40(2): 345-349.

Sanders, W. G., \& Tuschke, A. 2007. The Adoption of Institutionally Contested Organizational Practices: the Emergence of Stock Option Pay in Germany. Academy of Management Journal, 50(1): 33-56.

Shaver, J. M. 2007. Interpreting empirical results in strategy and management research.

Research Methodology in Strategy and Management, 4: 273-293.

Simmel, G. 1950. The sociology of Georg Simmel. New York: Free Press.

Stevenson, R. W. 1993, June 22. In a Czech Plant, VW Shows How to Succeed in the East. New York Times, A.1.

Stone, B. 2009, August 4. Google Chief Gives Up Board Seat at Apple. The New York Times.

Sytch, M., \& Tatarynowicz, A. 2013. Friends and Foes: The Dynamics of Dual Social Structures. Academy of Management Journal, forthcoming.

Tuschke, A., Sanders, W. G., \& Hernandez, E. 2014. Whose experience matters in the boardroom? The effects of experiential and vicarious learning on emerging market entry. Strategic Management Journal, 35(3): 398-418.

Useem, M. 1984. Corporate Social And Political Action. California Management Review, 26(2): 141-154.

Westphal, J. D. 1999. Collaboration in the Boardroom: Behavioral and Performance Consequences of CEO-Board Social Ties. Academy of Management Journal, 42(1): 724.

Wooldridge, J. M. 2002. Econometric analysis of cross section and panel data. Cambridge, MA: MIT Press.

Zaheer, A., \& Bell, G. G. 2005. Benefiting from Network Position: Firm Capabilities, Structural Holes, and Performance. Strategic Management Journal, 26(9): 809-825.

Zaheer, A., McEvily, B., \& Perrone, V. 1998. Does trust matter? Exploring the effects of interorganizational and interpersonal trust on performance. Organization Science, 9(2): $141-159$. 
Figure 1

Different Ways of Creating Indirect Competitor Links via Board Interlocks

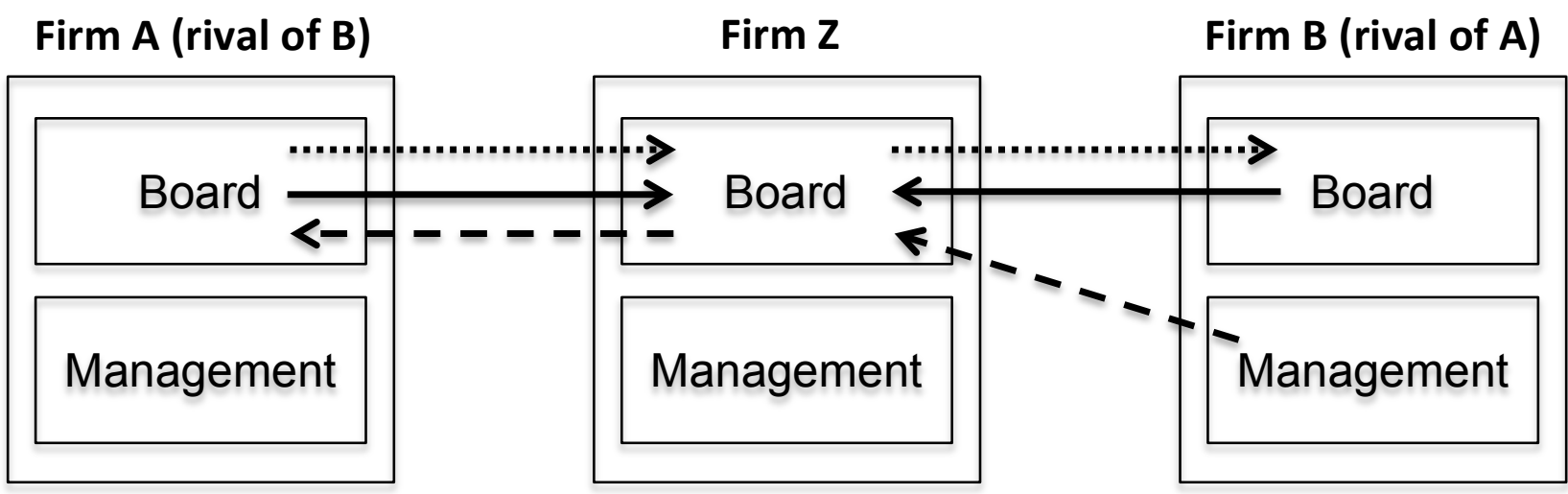




\section{Figure 2 \\ Illustration of Indirect Links to Competitors}

NOTES:

- $\quad$ Firms highlighted in GRAY are in the same industry as the focal firm (IWKA)

- This is an example from a firm with a relatively small network (only four partners) used for illustrative purposes. It was used here because its small size makes its depiction straightforward. While each of IWKA's partners generates at least one indirect link to competitors, most firms in the sample have much larger networks (e.g. mean degree centrality in the sample is close to 19) in which several partners create no indirect links to competitors.

- Links between IWKA's direct partners are not included for simplification. Most ego networks in the sample have at least some ties among alters.

- Please refer to the text for a description of how indirect ties to competitors are calculated at the ego network level.

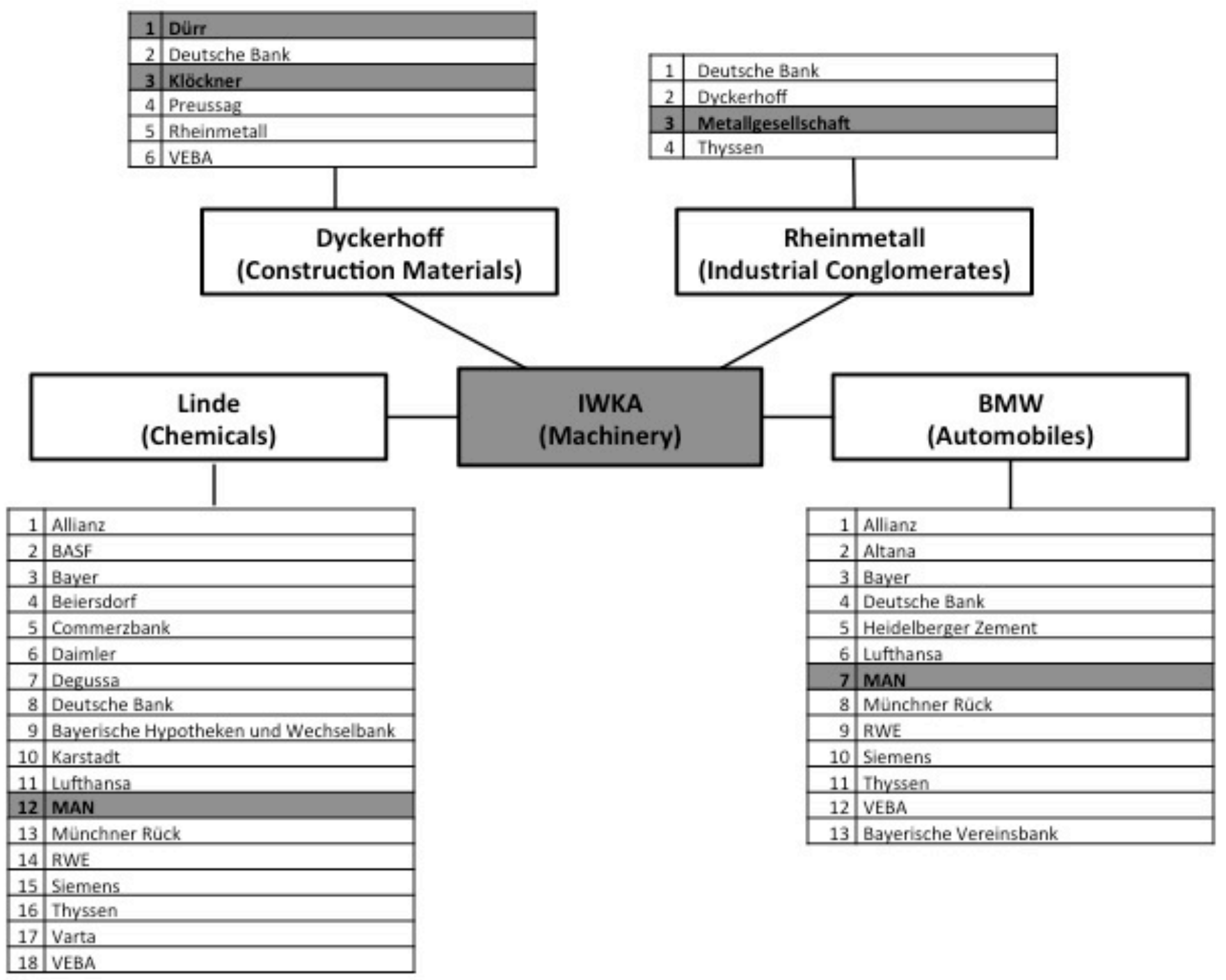


Figure 3a

Eastern European Experience * Indirect Competitor Links: Effect on Tie Termination

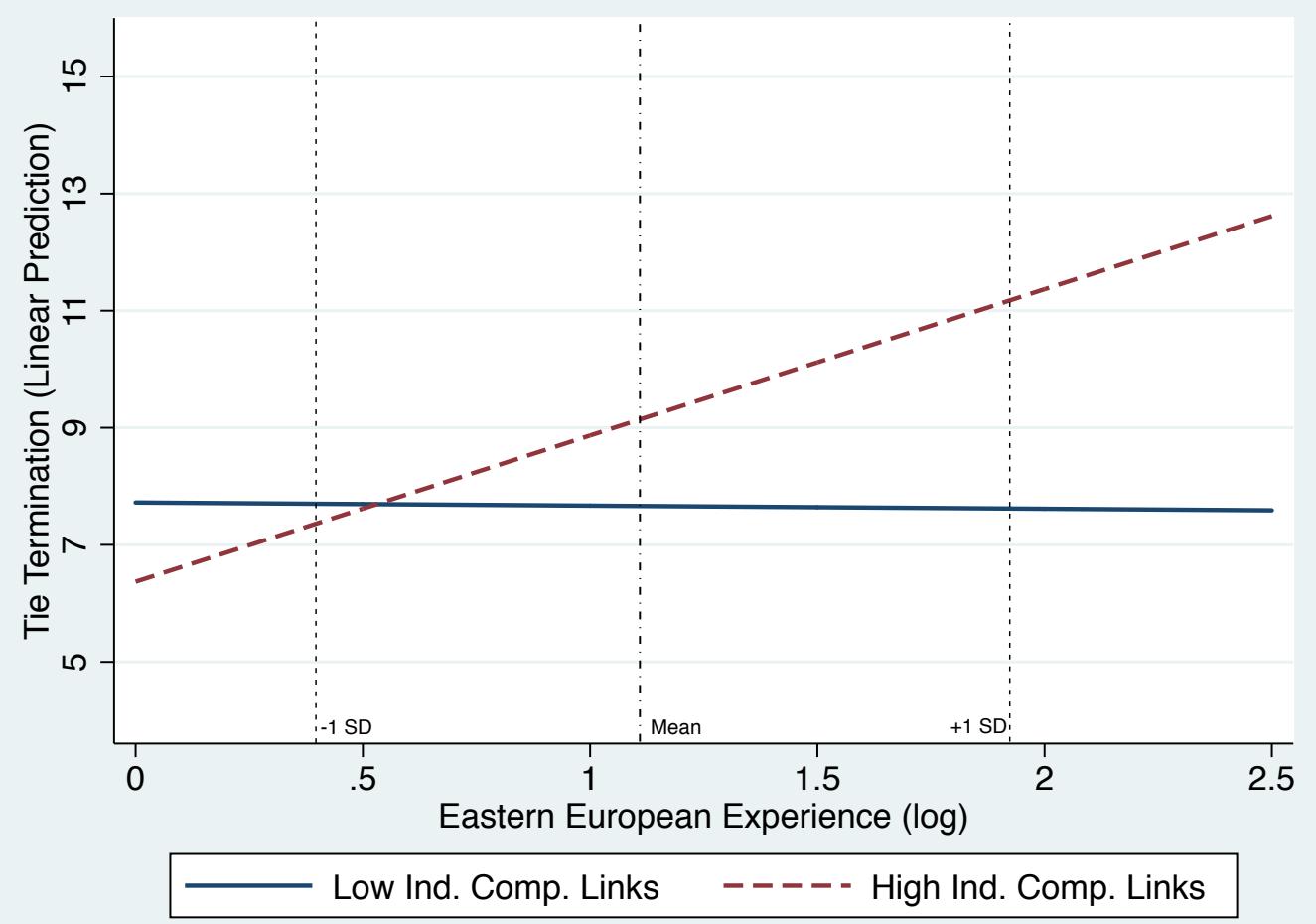

Figure 3b

Eastern European Experience * Indirect Competitor Links: Effect on Tie Addition

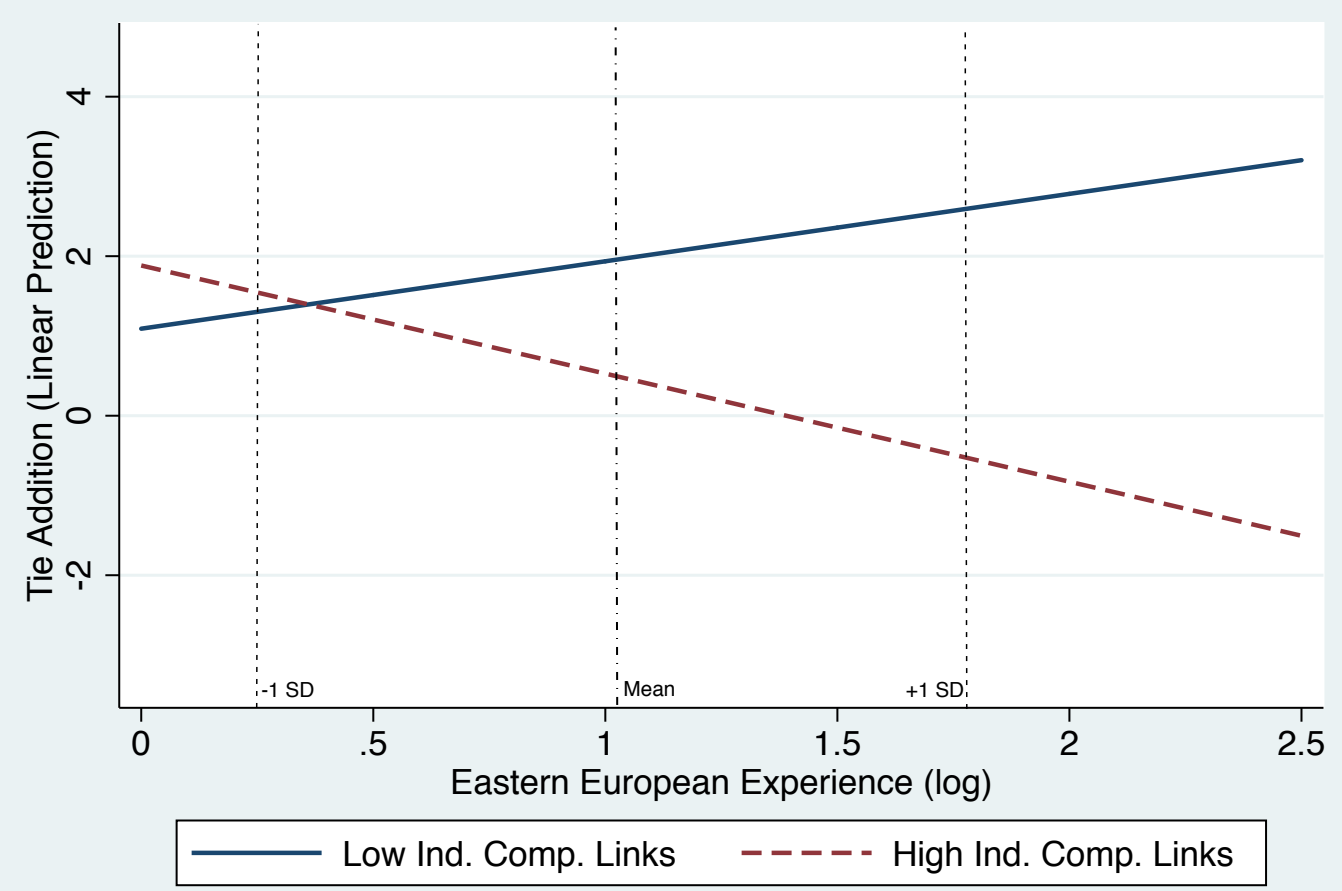


Figure 3c

Eastern European Experience * Indirect Competitor Links: Effect on Closure

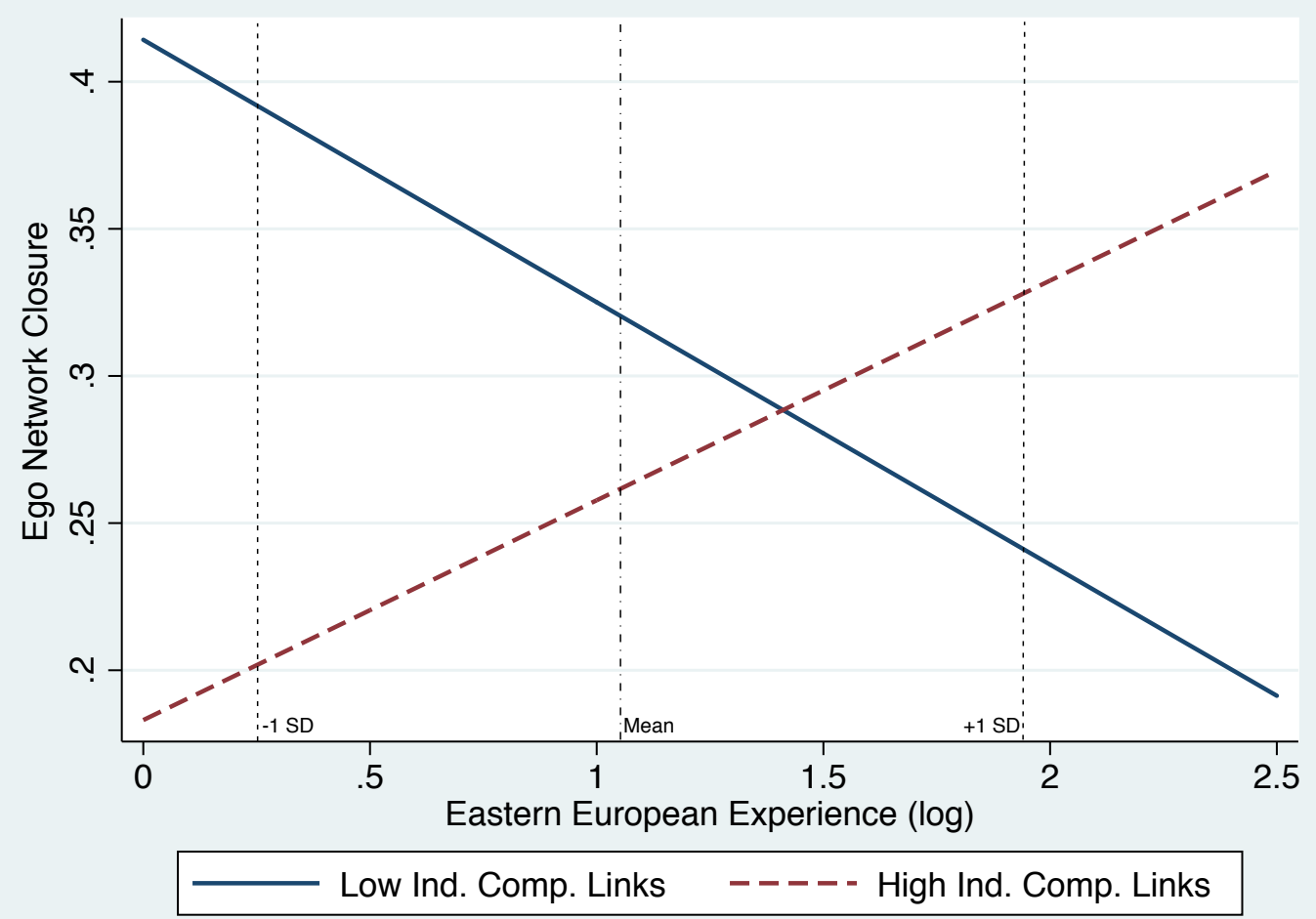




\section{Table 1a}

$\mathrm{F}=$ Focal Firm

$\mathrm{P}=$ Partner

Descriptive Statistics and Correlations (Dyadic Samples)

Note: The numbers below are based on the combined samples for the analysis of tie additions and deletions to avoid creating two nearly identical tables. Summary statistics and correlations are highly similar but may vary slightly across subsamples.

\begin{tabular}{|c|c|c|c|c|c|c|c|c|c|c|c|c|c|c|c|c|c|c|c|c|c|c|c|c|c|c|c|c|c|c|c|}
\hline Variable & Mean & SD & Min & Max & 1 & 2 & 3 & 4 & 5 & 6 & 7 & 8 & 9 & 10 & 11 & 12 & 13 & 14 & 15 & 16 & 17 & 18 & 19 & 20 & 21 & 22 & 23 & 24 & 25 & 26 & 27 \\
\hline 1 Terminated & 0.19 & 0.39 & 0 & 1 & & & & & & & & & & & & & & & & & & & & & & & & & & & \\
\hline 2 Added & 0.13 & 0.34 & 0 & 1 & $N / A$ & & & & & & & & & & & & & & & & & & & & & & & & & & \\
\hline $3 \mathrm{~F}$ Ind. Comp. Links & 0.53 & 0.84 & 0 & 6 & .01 & .00 & & & & & & & & & & & & & & & & & & & & & & & & & \\
\hline $4 \mathrm{~F} \mathrm{EE}$ experience & 1.08 & 0.76 & 0 & 2.64 & .12 & .09 & -.09 & & & & & & & & & & & & & & & & & & & & & & & & \\
\hline 5 Relative history & 0.95 & 3.82 & -13 & 13 & .12 & -.05 & -.50 & .19 & & & & & & & & & & & & & & & & & & & & & & & \\
\hline $6 \mathrm{P}$ Ind. Comp. Links & 0.53 & 0.84 & 0 & 6 & .01 & .00 & -.04 & .05 & .01 & & & & & & & & & & & & & & & & & & & & & & \\
\hline $7 \mathrm{EE}$ experience diff. & 0.01 & 3.06 & -12 & 12 & .00 & .00 & -.15 & .50 & .10 & .15 & & & & & & & & & & & & & & & & & & & & & \\
\hline $8 \mathrm{~F}$ Degree centrality & 18.98 & 10.58 & 0 & 43.05 & -.05 & .04 & -.09 & .21 & .13 & .32 & .24 & & & & & & & & & & & & & & & & & & & & \\
\hline 9 F Profitability & 0.03 & 0.05 & -0.31 & 0.41 & .04 & -.01 & -.05 & .05 & .03 & -.07 & -.02 & -.19 & & & & & & & & & & & & & & & & & & & \\
\hline $10 \mathrm{~F}$ Foreign sales & 0.49 & 0.23 & 0 & 0.89 & .06 & .02 & .22 & .32 & -.08 & .01 & .12 & .08 & .08 & & & & & & & & & & & & & & & & & & \\
\hline $11 \mathrm{~F}$ Closure & 0.19 & 0.18 & 0 & 1 & .02 & -.04 & .04 & -.13 & -.07 & -19 & -.12 & -.55 & .20 & -.06 & & & & & & & & & & & & & & & & & \\
\hline 12 F Stock option exp. & 0.18 & 0.38 & 0 & 1 & .12 & .00 & -.08 & .42 & .14 & .01 & .13 & .10 & .06 & .23 & -.05 & & & & & & & & & & & & & & & & \\
\hline 13 F CEOs on board & 1.18 & 1.19 & 0 & 6 & -.07 & -.01 & .01 & .04 & .00 & .21 & .13 & .56 & -.17 & .03 & -.31 & .03 & & & & & & & & & & & & & & & \\
\hline $14 \mathrm{~F}$ Equity owned by others & 0.09 & 0.16 & 0 & 0.80 & .00 & .01 & .00 & .06 & .01 & .04 & .00 & .18 & -.08 & -.14 & -.13 & .02 & .23 & & & & & & & & & & & & & & \\
\hline $15 \mathrm{~F}$ Equity owned in others & 0.06 & 0.15 & 0 & 0.99 & -.01 & -.03 & .02 & .13 & -.02 & .10 & .15 & .30 & -.14 & -.08 & -.13 & .06 & .19 & .07 & & & & & & & & & & & & & \\
\hline 16 F Director busyness & 0.77 & 0.44 & 0 & 4.50 & -.08 & .04 & .02 & .04 & -.01 & .19 & .06 & .59 & -.06 & .13 & -.36 & -.15 & .45 & .24 & .17 & & & & & & & & & & & & \\
\hline $17 \mathrm{~F}$ Acquisition exp. & 1.59 & 1.06 & 0 & 4.36 & .06 & .07 & -.14 & .55 & .19 & .18 & .34 & .51 & -.08 & .19 & -.28 & .30 & .23 & .01 & .21 & .17 & & & & & & & & & & & \\
\hline 18 P Degree centrality & 18.85 & 10.62 & 0 & 43.05 & -.05 & .04 & .33 & -.03 & -.09 & -.08 & -.24 & .02 & .00 & .00 & -.07 & -.08 & .01 & .01 & -.02 & .06 & -.05 & & & & & & & & & & \\
\hline 19 P Profitability & 0.03 & 0.05 & -0.31 & 0.41 & .04 & -.01 & -.07 & .08 & .03 & -.06 & .02 & .00 & .01 & .01 & .03 & .06 & -.01 & .00 & .01 & -.03 & .06 & -.18 & & & & & & & & & \\
\hline 20 P Foreign sales & 0.49 & 0.23 & 0 & 0.89 & .06 & .01 & .02 & .16 & .02 & .22 & -.12 & -.01 & .01 & .09 & -.03 & .13 & .02 & .00 & .01 & -.02 & .09 & .08 & .08 & & & & & & & & \\
\hline $21 \mathrm{P}$ Closure & 0.19 & 0.18 & 0 & 1 & .02 & -.04 & -.19 & -.01 & .06 & .03 & .12 & -.07 & .02 & -.03 & .08 & .06 & -.06 & .00 & -.02 & -.09 & -.02 & -.55 & .20 & -.07 & & & & & & & \\
\hline $22 \mathrm{P}$ EE experience & 1.08 & 0.76 & 0 & 2.64 & .12 & .09 & .05 & .38 & .11 & -.09 & -.50 & -.03 & .08 & .17 & .00 & .30 & -.07 & .03 & -.04 & -.07 & .22 & .22 & .05 & .32 & -.13 & & & & & & \\
\hline 23 P Stock option exp. & 0.17 & 0.38 & 0 & 1 & .13 & .00 & .02 & .30 & .05 & -.08 & -.14 & -.09 & .06 & .14 & .06 & .40 & -.05 & .01 & .00 & -.14 & .14 & .10 & .06 & .23 & -.05 & .42 & & & & & \\
\hline 24 P CEOs on board & 1.18 & 1.19 & 0 & 6 & -.07 & -.01 & .21 & -.07 & -.10 & .02 & -.14 & .01 & -.01 & .02 & -.05 & -.05 & .02 & .02 & -.01 & .07 & -.05 & .56 & -.17 & .03 & -.31 & .04 & .03 & & & & \\
\hline $25 \mathrm{P}$ Equity owned by others & 0.09 & 0.16 & 0 & 0.80 & .00 & .01 & .05 & .03 & .02 & .01 & -.01 & .01 & .00 & -.01 & .00 & .01 & .02 & .02 & .02 & .01 & .02 & .19 & -.08 & -.14 & -.13 & .06 & .01 & .24 & & & \\
\hline $26 \mathrm{P}$ Equity owned in others & 0.06 & 0.15 & 0 & 0.99 & -.01 & -.03 & .10 & -.04 & -.04 & .02 & -.15 & -.02 & .01 & .01 & -.02 & .00 & -.01 & .02 & -.02 & .02 & -.05 & .30 & -.15 & -.08 & -.13 & .13 & .07 & .19 & .08 & & \\
\hline 27 P Director busyness & 0.77 & 0.44 & 0 & 4.50 & -.08 & .04 & .20 & -.07 & -.07 & .03 & -.06 & .06 & -.03 & -.01 & -.09 & -.13 & .07 & .02 & .01 & .11 & -.03 & .59 & -.06 & .13 & -.36 & .04 & -.15 & .45 & .24 & .17 & \\
\hline 28 P Acquisition exp. & 1.59 & 1.06 & 0 & 4.36 & .06 & .07 & .18 & .22 & .00 & -.14 & -.34 & -.05 & .06 & .10 & .00 & .14 & -.05 & .03 & -.05 & -.03 & .09 & .51 & -.09 & .19 & -.28 & .56 & .30 & .23 & .01 & .21 & .17 \\
\hline
\end{tabular}


Table 1b

$F=$ Focal Firm

$\mathrm{P}=$ Partner

Descriptive Statistics and Correlations (Ego Network Sample)

\begin{tabular}{|c|c|c|c|c|c|c|c|c|c|c|c|c|c|c|c|c|c|c|c|c|c|c|c|c|c|c|c|}
\hline Variable & Mean & SD & Min & Max & 1 & 2 & 3 & 4 & 5 & 6 & 7 & 8 & 9 & 10 & 11 & 12 & 13 & 14 & 15 & 16 & 17 & 18 & 19 & 20 & 21 & 22 & 23 \\
\hline 1Closure & 0.32 & 0.29 & 0.09 & 1 & & & & & & & & & & & & & & & & & & & & & & & \\
\hline 2F EE experience & 1.08 & 0.77 & 0 & 2.64 & -.21 & & & & & & & & & & & & & & & & & & & & & & \\
\hline 3F Ind. Comp. Links & 0.61 & 0.73 & 0 & 3.64 & -.18 & -.03 & & & & & & & & & & & & & & & & & & & & & \\
\hline 4Relative History & 1.86 & 3.36 & -11 & 12.67 & .06 & .21 & -.55 & & & & & & & & & & & & & & & & & & & & \\
\hline 5F Degree centrality & 14.53 & 10.90 & 1.38 & 43.05 & -.72 & .22 & .03 & .00 & & & & & & & & & & & & & & & & & & & \\
\hline 6P Degree centrality & 19.93 & 6.12 & 1.38 & 31.94 & -.68 & .16 & .11 & -.09 & .57 & & & & & & & & & & & & & & & & & & \\
\hline 7EE Experience diff. & -0.33 & 2.48 & -9 & 8.15 & -.08 & .55 & -.11 & .16 & .18 & -.01 & & & & & & & & & & & & & & & & & \\
\hline 8F Profitability & 0.03 & 0.05 & -0.31 & 0.41 & .21 & .02 & -.09 & .04 & -.21 & -.16 & .02 & & & & & & & & & & & & & & & & \\
\hline 9F Foreign Sales & 0.48 & 0.25 & 0 & 0.89 & -.19 & .35 & .33 & -.13 & .13 & .19 & .15 & .07 & & & & & & & & & & & & & & & \\
\hline 10F Stock Option exp. & 0.19 & 0.39 & 0 & 1 & -.15 & .45 & -.04 & .11 & .16 & .04 & .12 & .03 & .27 & & & & & & & & & & & & & & \\
\hline $11 \mathrm{~F}$ CEOs on board & 0.89 & 1.12 & 0 & 6 & -.40 & .11 & .05 & -.05 & .62 & .38 & .13 & -.17 & .07 & .12 & & & & & & & & & & & & & \\
\hline $12 \mathrm{~F}$ Equity owned by others & 0.07 & 0.15 & 0 & 0.80 & -.26 & .07 & .03 & -.07 & .25 & .15 & -.02 & -.12 & -.11 & .00 & .23 & & & & & & & & & & & & \\
\hline 13F Equity owned in others & 0.04 & 0.13 & 0 & 0.99 & -.19 & .13 & .03 & -.05 & .33 & .14 & .13 & -.12 & -.04 & .13 & .21 & .09 & & & & & & & & & & & \\
\hline 14F Director busyness & 0.65 & 0.47 & 0 & 4.50 & -.45 & .06 & .12 & -.10 & .54 & .47 & -.05 & -.03 & .14 & -.07 & .38 & .24 & .16 & & & & & & & & & & \\
\hline 15P Profitability & 0.03 & 0.03 & -0.31 & 0.22 & .11 & -.07 & -.05 & .04 & -.06 & -.21 & -.05 & .09 & -.05 & -.02 & -.06 & .00 & -.02 & -.04 & & & & & & & & & \\
\hline 16P Foreign Sales & 0.48 & 0.14 & 0 & 0.89 & -.30 & .40 & .06 & .00 & .17 & .28 & -.08 & -.04 & .24 & .36 & .13 & .00 & .11 & .09 & .02 & & & & & & & & \\
\hline 17P EE experience & 3.54 & 2.48 & 0 & 14 & -.13 & .48 & .04 & .14 & .10 & .20 & -.35 & -.02 & .22 & .45 & .05 & .06 & .03 & .08 & -.06 & .47 & & & & & & & \\
\hline 18P CEOs on board & 1.19 & 0.64 & 0 & 4.50 & -.43 & .05 & .04 & -.09 & .43 & .68 & -.07 & -.16 & .15 & .02 & .39 & .11 & .12 & .40 & -.22 & .18 & .17 & & & & & & \\
\hline 19P Equity owned by others & 0.10 & 0.07 & 0 & 0.51 & -.13 & .11 & -.09 & .03 & .12 & .27 & .03 & .05 & .01 & .03 & .12 & .10 & .05 & .10 & -.17 & -.02 & .12 & .22 & & & & & \\
\hline 20P Equity owned in others & 0.06 & 0.06 & 0 & 0.50 & -.22 & .03 & .04 & -.03 & .20 & .37 & -.09 & -.06 & .11 & .24 & .15 & .13 & .00 & .11 & -.20 & .09 & .24 & .25 & .13 & & & & \\
\hline 21P Director busyness & 0.74 & 0.25 & 0 & 1.35 & -.52 & -.06 & .05 & -.08 & .45 & .69 & .12 & -.13 & .05 & -.26 & .31 & .10 & .10 & .34 & -.10 & .08 & -.23 & .43 & .23 & .17 & & & \\
\hline 22F Acquisition exp. & 1.43 & 1.07 & 0 & 4.36 & -.36 & .59 & -.12 & .22 & .51 & .30 & .32 & -.10 & .21 & .36 & .28 & .04 & .23 & .19 & -.08 & .27 & .39 & .19 & .15 & .09 & 12 & & \\
\hline 23P Acquisition exp. & 5.88 & 0.55 & 4.48 & 6.46 & .00 & .61 & -.02 & .21 & -.07 & -.04 & -.13 & .08 & .19 & .41 & -.08 & .03 & -.03 & -.07 & .02 & .39 & .77 & -.07 & .10 & -.01 & -.29 & .36 & \\
\hline 24Same industry partners & 5.91 & 16.20 & 0 & 100 & .15 & -.04 & .23 & -.25 & -.16 & -.10 & .01 & .01 & .11 & .00 & -.02 & -.03 & -.03 & -.08 & -.03 & .05 & -.08 & .01 & .03 & .00 & -.02 & -.17 & -.01 \\
\hline
\end{tabular}


Table 2

Probability of Tie Termination (Dyadic Level)

Fixed Effects Logit, robust standard errors $(* p<0.10, * * p<0.05, * * * p<0.01$, one tailed for hypotheses)

\begin{tabular}{|c|c|c|c|c|c|}
\hline & $\begin{array}{c}1 \\
\text { Controls }\end{array}$ & $\begin{array}{c}2 \\
\text { Main Effects } \\
\end{array}$ & $\begin{array}{c}3 \\
\text { Interaction }\end{array}$ & $\begin{array}{c}4 \\
\text { Low ICL }\end{array}$ & $\begin{array}{c}5 \\
\text { High ICL }\end{array}$ \\
\hline Indirect Competitor Links (ICL) & & $0.557 * *$ & $-0.677^{*} *$ & & $-1.346 * * *$ \\
\hline (partner creates for firm) & & $(0.237)$ & $(0.301)$ & & $(0.364)$ \\
\hline \multirow[t]{2}{*}{ EE experience } & & $0.613^{*}$ & -0.053 & $-2.321 * * *$ & $2.046 * * *$ \\
\hline & & $(0.403)$ & $(0.437)$ & $(0.855)$ & $(0.606)$ \\
\hline \multirow[t]{2}{*}{ EE Experience $\mathrm{XICL}$} & & & $1.276 * * *$ & & \\
\hline & & & $(0.321)$ & & \\
\hline \multirow[t]{2}{*}{ Relative history } & $0.745 * * *$ & $0.742 * * *$ & $0.858 * * *$ & $3.137 * * *$ & $1.431 * * *$ \\
\hline & $(0.080)$ & $(0.077)$ & $(0.088)$ & $(0.286)$ & $(0.304)$ \\
\hline Indirect Competitor Links & 0.045 & -0.001 & 0.027 & 0.344 & -0.216 \\
\hline (firm creates for partner) & $(0.162)$ & $(0.165)$ & $(0.163)$ & $(0.363)$ & $(0.304)$ \\
\hline \multirow[t]{2}{*}{ EE experience difference } & 0.032 & -0.088 & -0.077 & 0.192 & -0.089 \\
\hline & $(0.065)$ & $(0.108)$ & $(0.110)$ & $(0.237)$ & $(0.153)$ \\
\hline \multirow[t]{2}{*}{ Firm degree centrality } & -0.004 & -0.001 & 0.001 & 0.063 & -0.005 \\
\hline & $(0.024)$ & $(0.024)$ & $(0.025)$ & $(0.041)$ & $(0.050)$ \\
\hline \multirow[t]{2}{*}{ Firm profitability } & $2.996 * *$ & $2.990 * *$ & $2.983 * *$ & 2.043 & $5.842 * *$ \\
\hline & $(1.390)$ & $(1.346)$ & $(1.212)$ & $(2.967)$ & $(2.448)$ \\
\hline \multirow[t]{2}{*}{ Firm foreign sales } & $2.292 *$ & $2.412 * *$ & $2.265^{*}$ & -3.638 & $6.285^{* * *}$ \\
\hline & $(1.176)$ & (1.198) & $(1.198)$ & $(2.233)$ & $(2.205)$ \\
\hline \multirow[t]{2}{*}{ Firm constraint } & 0.925 & 0.881 & 1.066 & 0.951 & -1.203 \\
\hline & $(0.688)$ & $(0.700)$ & $(0.704)$ & $(0.879)$ & $(1.564)$ \\
\hline \multirow[t]{2}{*}{ Firm stock option experience } & -0.365 & -0.367 & -0.339 & $-1.680 * * *$ & -0.361 \\
\hline & $(0.231)$ & $(0.232)$ & $(0.233)$ & $(0.439)$ & $(0.417)$ \\
\hline \multirow[t]{2}{*}{ Firm CEOs on board } & $-0.180 *$ & -0.146 & -0.139 & $-0.610 * *$ & 0.149 \\
\hline & $(0.107)$ & $(0.108)$ & $(0.109)$ & $(0.275)$ & $(0.173)$ \\
\hline \multirow[t]{2}{*}{ Firm equity owned by other firms } & 1.011 & 0.882 & 0.776 & 1.499 & 1.470 \\
\hline & $(0.831)$ & $(0.846)$ & $(0.892)$ & $(1.661)$ & $(1.077)$ \\
\hline \multirow[t]{2}{*}{ Firm equity owned in other firms } & 0.106 & 0.164 & 0.465 & 1.173 & 0.803 \\
\hline & $(0.637)$ & $(0.629)$ & $(0.601)$ & $(1.126)$ & $(0.869)$ \\
\hline \multirow[t]{2}{*}{ Firm director busyness } & $0.507 * *$ & $0.534 * *$ & $0.571 * *$ & $1.135^{* * *}$ & 0.719 \\
\hline & $(0.221)$ & $(0.223)$ & $(0.224)$ & $(0.335)$ & $(0.641)$ \\
\hline \multirow[t]{2}{*}{ Firm acquisition experience } & $0.642 * * *$ & $0.617 * * *$ & $0.642 * * *$ & -0.068 & $0.966 * * *$ \\
\hline & $(0.185)$ & $(0.188)$ & $(0.187)$ & $(0.342)$ & $(0.371)$ \\
\hline \multirow[t]{2}{*}{ Partner degree centrality } & 0.038 & 0.029 & 0.029 & $0.098^{* *}$ & 0.025 \\
\hline & $(0.023)$ & $(0.023)$ & $(0.022)$ & $(0.050)$ & $(0.039)$ \\
\hline \multirow[t]{2}{*}{ Partner profitability } & $2.119 *$ & 1.967 & 1.998 & -2.520 & 1.994 \\
\hline & $(1.250)$ & $(1.226)$ & $(1.236)$ & $(2.346)$ & $(2.716)$ \\
\hline \multirow[t]{2}{*}{ Partner foreign sales } & $1.833^{*}$ & 1.635 & 1.304 & $-4.381 * *$ & 1.414 \\
\hline & $(1.027)$ & (1.029) & $(1.027)$ & $(1.855)$ & $(2.033)$ \\
\hline \multirow[t]{2}{*}{ Partner constraint } & 0.548 & 0.488 & 0.462 & -1.207 & 5.309 \\
\hline & $(0.688)$ & $(0.660)$ & $(0.675)$ & $(0.946)$ & $(3.857)$ \\
\hline \multirow[t]{2}{*}{ Partner EE experience } & $0.541 *$ & 0.107 & -0.035 & $-1.706 * *$ & 0.904 \\
\hline & $(0.298)$ & $(0.397)$ & $(0.412)$ & $(0.682)$ & $(0.615)$ \\
\hline
\end{tabular}




\begin{tabular}{|c|c|c|c|c|c|}
\hline \multirow[t]{2}{*}{ Partner stock option experience } & -0.045 & -0.125 & -0.171 & $-1.586 * * *$ & $0.771 * *$ \\
\hline & $(0.232)$ & $(0.227)$ & $(0.228)$ & $(0.413)$ & $(0.377)$ \\
\hline \multirow[t]{2}{*}{ Partner CEOs on board } & -0.103 & -0.114 & -0.132 & -0.036 & $-0.380 * *$ \\
\hline & $(0.102)$ & $(0.106)$ & $(0.105)$ & $(0.255)$ & $(0.155)$ \\
\hline \multirow[t]{2}{*}{ Partner equity owned by other firms } & 0.627 & 0.706 & 0.680 & 0.234 & -1.484 \\
\hline & $(0.800)$ & $(0.799)$ & $(0.784)$ & (1.159) & $(1.385)$ \\
\hline \multirow[t]{2}{*}{ Partner equity owned in other firms } & 0.669 & 0.731 & 0.851 & -0.024 & 0.799 \\
\hline & $(0.628)$ & $(0.662)$ & $(0.655)$ & $(1.198)$ & $(0.970)$ \\
\hline \multirow[t]{2}{*}{ Partner director busyness } & -0.023 & -0.028 & 0.013 & -0.007 & 0.249 \\
\hline & $(0.192)$ & $(0.191)$ & $(0.185)$ & $(0.263)$ & $(0.434)$ \\
\hline \multirow[t]{2}{*}{ Partner acquisition experience } & $0.713 * * *$ & $0.682 * * *$ & $0.650 * * *$ & 0.234 & $0.775 * *$ \\
\hline & $(0.187)$ & $(0.191)$ & $(0.194)$ & $(0.400)$ & $(0.334)$ \\
\hline Dyad, Firm, Partner, Industry FE & $\mathrm{Y}$ & $\mathrm{Y}$ & $\mathrm{Y}$ & $\mathrm{Y}$ & $\mathrm{Y}$ \\
\hline Sample size (firm-partner years) & 4583 & 4583 & 4583 & 2760 & 1390 \\
\hline Model Chi2 & $168.169 * * *$ & $198.981 * * *$ & $191.632 * * *$ & $249.483^{* * *}$ & $83.984 * * *$ \\
\hline Pseudo R2 & 0.3641 & 0.3693 & 0.3860 & 0.7355 & 0.3976 \\
\hline
\end{tabular}


Table 3

Probability of Tie Formation (Dyadic Level)

Fixed Effects Logit, robust standard errors $(* p<0.10, * * p<0.05, * * * p<0.01$, one tailed for hypotheses)

\begin{tabular}{|c|c|c|c|c|c|}
\hline & $\begin{array}{c}6 \\
\text { Controls } \\
\end{array}$ & $\begin{array}{c}7 \\
\text { Main Effects } \\
\end{array}$ & $\begin{array}{c}8 \\
\text { Interaction } \\
\end{array}$ & $\begin{array}{c}9 \\
\text { Low ICL }\end{array}$ & $\begin{array}{c}10 \\
\text { High ICL }\end{array}$ \\
\hline $\begin{array}{l}\text { Indirect Competitor Links (ICL) } \\
\text { (partner creates for firm) }\end{array}$ & & $\begin{array}{l}-0.613^{* * *} \\
(0.229)\end{array}$ & $\begin{array}{r}0.396 \\
(0.256)\end{array}$ & & $\begin{array}{l}0.983^{* * *} \\
(0.257)\end{array}$ \\
\hline EE experience & & $\begin{array}{l}0.377^{* *} \\
(0.200)\end{array}$ & $\begin{array}{l}0.845^{* * *} \\
(0.219)\end{array}$ & $\begin{array}{l}2.267 * * * \\
(0.582)\end{array}$ & $\begin{array}{l}-0.574^{*} \\
(0.410)\end{array}$ \\
\hline EE Experience X ICL & & & $\begin{array}{l}-1.100^{* * *} \\
(0.190)\end{array}$ & & \\
\hline Relative history & $\begin{array}{l}-0.383 * * * \\
(0.043)\end{array}$ & $\begin{array}{l}-0.401 * * * \\
(0.043)\end{array}$ & $\begin{array}{l}-0.520^{* * *} \\
(0.053)\end{array}$ & $\begin{array}{l}-5.597^{* * *} \\
(1.547)\end{array}$ & $\begin{array}{l}-0.808 * * * \\
(0.111)\end{array}$ \\
\hline $\begin{array}{l}\text { Indirect Competitor Links } \\
\text { (firm creates for partner) }\end{array}$ & $\begin{array}{r}-0.046 \\
(0.148)\end{array}$ & $\begin{array}{r}-0.034 \\
(0.148)\end{array}$ & $\begin{array}{r}-0.031 \\
(0.149)\end{array}$ & $\begin{array}{r}-0.179 \\
(0.311)\end{array}$ & $\begin{array}{r}-0.044 \\
(0.283)\end{array}$ \\
\hline EE experience difference & $\begin{array}{l}0.162 * * * \\
(0.032)\end{array}$ & $\begin{array}{c}0.087^{*} \\
(0.050)\end{array}$ & $\begin{array}{r}0.055 \\
(0.051)\end{array}$ & $\begin{array}{r}0.135 \\
(0.166)\end{array}$ & $\begin{array}{r}0.031 \\
(0.111)\end{array}$ \\
\hline Firm degree centrality & $\begin{array}{r}0.019 \\
(0.017)\end{array}$ & $\begin{array}{r}0.018 \\
(0.018)\end{array}$ & $\begin{array}{r}0.011 \\
(0.018)\end{array}$ & $\begin{array}{r}0.051 \\
(0.042)\end{array}$ & $\begin{array}{r}0.045 \\
(0.028)\end{array}$ \\
\hline Firm profitability & $\begin{array}{r}-1.310 \\
(1.161)\end{array}$ & $\begin{array}{r}-1.400 \\
(1.151)\end{array}$ & $\begin{array}{r}-0.848 \\
(1.193)\end{array}$ & $\begin{array}{r}-0.501 \\
(2.247)\end{array}$ & $\begin{array}{r}-1.935 \\
(2.030)\end{array}$ \\
\hline Firm foreign sales & $\begin{array}{r}-1.062 \\
(0.674)\end{array}$ & $\begin{array}{r}-1.093 \\
(0.666)\end{array}$ & $\begin{array}{r}-0.924 \\
(0.675)\end{array}$ & $\begin{array}{r}1.428 \\
(1.576)\end{array}$ & $\begin{array}{l}-3.945^{* *} \\
(1.533)\end{array}$ \\
\hline Firm constraint & $\begin{array}{r}-0.597 \\
(0.379)\end{array}$ & $\begin{array}{l}-0.634 * \\
(0.372)\end{array}$ & $\begin{array}{c}-0.734 * \\
(0.378)\end{array}$ & $\begin{array}{r}-0.933 \\
(0.693)\end{array}$ & $\begin{array}{l}-1.907^{* * *} \\
(0.733)\end{array}$ \\
\hline Firm stock option experience & $\begin{array}{r}-0.219 \\
(0.203)\end{array}$ & $\begin{array}{r}-0.195 \\
(0.200)\end{array}$ & $\begin{array}{r}-0.190 \\
(0.202)\end{array}$ & $\begin{array}{r}0.510 \\
(0.316)\end{array}$ & $\begin{array}{r}-0.091 \\
(0.431)\end{array}$ \\
\hline Firm CEOs on board & $\begin{array}{l}-0.148 * \\
(0.081)\end{array}$ & $\begin{array}{l}-0.140 * \\
(0.082)\end{array}$ & $\begin{array}{l}-0.153^{*} \\
(0.083)\end{array}$ & $\begin{array}{l}-0.189 * \\
(0.112)\end{array}$ & $\begin{array}{r}-0.200 \\
(0.178)\end{array}$ \\
\hline Firm equity owned by other firms & $\begin{array}{l}-0.305 \\
(0.530)\end{array}$ & $\begin{array}{l}-0.457 \\
(0.528)\end{array}$ & $\begin{array}{l}-0.518 \\
(0.547)\end{array}$ & $\begin{array}{r}0.443 \\
(0.953)\end{array}$ & $\begin{array}{l}-0.086 \\
(0.695)\end{array}$ \\
\hline Firm equity owned in other firms & $\begin{array}{l}-1.258^{* *} \\
(0.558)\end{array}$ & $\begin{array}{l}-1.185^{* *} \\
(0.529)\end{array}$ & $\begin{array}{l}-1.207^{* *} \\
(0.516)\end{array}$ & $\begin{array}{r}-0.462 \\
(0.987)\end{array}$ & $\begin{array}{l}-2.745^{* * *} \\
(0.997)\end{array}$ \\
\hline Firm director busyness & $\begin{array}{c}0.384^{*} \\
(0.203)\end{array}$ & $\begin{array}{c}0.349 * \\
(0.203)\end{array}$ & $\begin{array}{c}0.380 * \\
(0.199)\end{array}$ & $\begin{array}{r}0.025 \\
(0.445)\end{array}$ & $\begin{array}{r}0.322 \\
(0.520)\end{array}$ \\
\hline Firm acquisition experience & $\begin{array}{l}0.304 * * * \\
(0.111)\end{array}$ & $\begin{array}{l}0.291^{* * *} \\
(0.113)\end{array}$ & $\begin{array}{l}0.280 * * \\
(0.114)\end{array}$ & $\begin{array}{l}0.849 * * * \\
(0.226)\end{array}$ & $\begin{array}{r}0.018 \\
(0.245)\end{array}$ \\
\hline Partner degree centrality & $\begin{array}{r}0.008 \\
(0.017)\end{array}$ & $\begin{array}{r}0.019 \\
(0.018)\end{array}$ & $\begin{array}{r}0.019 \\
(0.018)\end{array}$ & $\begin{array}{r}0.058 \\
(0.047)\end{array}$ & $\begin{array}{r}-0.025 \\
(0.032)\end{array}$ \\
\hline Partner profitability & $\begin{array}{r}-0.163 \\
(1.120)\end{array}$ & $\begin{array}{r}-0.133 \\
(1.110)\end{array}$ & $\begin{array}{r}-0.232 \\
(1.112)\end{array}$ & $\begin{array}{r}-0.063 \\
(1.711)\end{array}$ & $\begin{array}{r}-2.818 \\
(4.010)\end{array}$ \\
\hline Partner foreign sales & $\begin{array}{r}-0.591 \\
(0.655)\end{array}$ & $\begin{array}{l}-0.754 \\
(0.659)\end{array}$ & $\begin{array}{r}-0.761 \\
(0.655)\end{array}$ & $\begin{array}{c}2.553^{*} \\
(1.479)\end{array}$ & $\begin{array}{r}-0.792 \\
(1.506)\end{array}$ \\
\hline Partner constraint & $\begin{array}{l}-0.670 * \\
(0.366)\end{array}$ & $\begin{array}{l}-0.649 * \\
(0.365)\end{array}$ & $\begin{array}{l}-0.700 * \\
(0.369)\end{array}$ & $\begin{array}{r}-0.745 \\
(0.516)\end{array}$ & $\begin{array}{l}-8.234^{*} \\
(4.288)\end{array}$ \\
\hline Partner EE experience & $\begin{array}{l}1.023 * * * \\
(0.157)\end{array}$ & $\begin{array}{l}0.756^{* * *} \\
(0.208)\end{array}$ & $\begin{array}{l}0.693^{* * *} \\
(0.209)\end{array}$ & $\begin{array}{l}2.172 * * * \\
(0.552)\end{array}$ & $\begin{array}{r}0.431 \\
(0.455)\end{array}$ \\
\hline
\end{tabular}




\begin{tabular}{|c|c|c|c|c|c|}
\hline \multirow[t]{2}{*}{ Partner stock option experience } & $-0.477 * *$ & $-0.504 * *$ & $-0.425^{* *}$ & $1.112 * * *$ & $-0.985 * *$ \\
\hline & $(0.211)$ & $(0.216)$ & $(0.217)$ & $(0.366)$ & $(0.406)$ \\
\hline \multirow[t]{2}{*}{ Partner CEOs on board } & $-0.157^{*}$ & $-0.176 * *$ & $-0.190 * *$ & -0.173 & -0.181 \\
\hline & $(0.084)$ & $(0.086)$ & $(0.088)$ & $(0.138)$ & $(0.154)$ \\
\hline \multirow[t]{2}{*}{ Partner equity owned by other firms } & -0.131 & -0.194 & -0.116 & 0.426 & -0.985 \\
\hline & $(0.539)$ & $(0.537)$ & $(0.565)$ & $(0.798)$ & $(0.982)$ \\
\hline \multirow[t]{2}{*}{ Partner equity owned in other firms } & $-1.247 * * *$ & $-1.265 * * *$ & $-1.376^{* * *}$ & -0.692 & $-1.646 *$ \\
\hline & $(0.451)$ & $(0.456)$ & $(0.456)$ & $(1.018)$ & $(0.908)$ \\
\hline \multirow[t]{2}{*}{ Partner director busyness } & $0.452 * *$ & $0.472 * *$ & $0.451 * *$ & 0.220 & $0.714^{*}$ \\
\hline & $(0.196)$ & $(0.202)$ & $(0.203)$ & $(0.323)$ & $(0.367)$ \\
\hline \multirow[t]{2}{*}{ Partner acquisition experience } & $0.288 * * *$ & $0.255^{* *}$ & $0.253^{* *}$ & $0.680 * * *$ & -0.389 \\
\hline & $(0.111)$ & $(0.111)$ & $(0.114)$ & $(0.229)$ & $(0.251)$ \\
\hline Dyad, Firm, Partner, Industry FE & Y & $\mathrm{Y}$ & Y & $Y$ & $\mathrm{Y}$ \\
\hline Sample size (firm-partner years) & 5626 & 5626 & 5626 & 3420 & 1670 \\
\hline Model Chi2 & $187.865^{* * *}$ & $185.629 * * *$ & $218.307^{* * *}$ & $110.412 * * *$ & $135.435 * * *$ \\
\hline Pseudo R2 & 0.1527 & 0.1597 & 0.1810 & 0.4824 & 0.2661 \\
\hline
\end{tabular}


Table 4

Network Closure (Ego Network Level)

Dynamic Panel Estimation, robust standard errors $(* p<0.10, * * p<0.05, * * * p<0.01$, one tailed for hypotheses)

\begin{tabular}{|c|c|c|c|}
\hline & $\begin{array}{c}11 \\
\text { Controls }\end{array}$ & $\begin{array}{c}12 \\
\text { Main Effects }\end{array}$ & $\begin{array}{c}13 \\
\text { Interaction } \\
\end{array}$ \\
\hline EE experience $\mathrm{X} I \mathrm{CL}$ & & & $\begin{array}{l}0.082^{* *} \\
(0.041)\end{array}$ \\
\hline Indirect Competitor Links (ICL) & & $\begin{array}{l}-0.040 * * \\
(0.020)\end{array}$ & $\begin{array}{l}-0.116^{* * *} \\
(0.040)\end{array}$ \\
\hline EE Experience & & $\begin{array}{r}-0.042 \\
(0.063)\end{array}$ & $\begin{array}{r}-0.089 \\
(0.080)\end{array}$ \\
\hline Lagged closure & $\begin{array}{l}0.558^{* * *} \\
(0.160)\end{array}$ & $\begin{array}{l}0.350 * * * \\
(0.127)\end{array}$ & $\begin{array}{l}0.366^{* * *} \\
(0.114)\end{array}$ \\
\hline Relative history & $\begin{array}{l}-0.031 * * * \\
(0.011)\end{array}$ & $\begin{array}{l}-0.033^{* * *} \\
(0.009)\end{array}$ & $\begin{array}{l}-0.018^{* *} \\
(0.008)\end{array}$ \\
\hline Firm degree centrality & $\begin{array}{c}0.006 * \\
(0.003)\end{array}$ & $\begin{array}{r}0.001 \\
(0.003)\end{array}$ & $\begin{array}{r}-0.002 \\
(0.003)\end{array}$ \\
\hline Partners' degree centrality (mean) & $\begin{array}{r}-0.001 \\
(0.005)\end{array}$ & $\begin{array}{r}-0.001 \\
(0.006)\end{array}$ & $\begin{array}{r}-0.000 \\
(0.005)\end{array}$ \\
\hline EE experience difference (mean) & $\begin{array}{r}0.004 \\
(0.007)\end{array}$ & $\begin{array}{r}0.015 \\
(0.016)\end{array}$ & $\begin{array}{r}0.007 \\
(0.020)\end{array}$ \\
\hline Firm profitability & $\begin{array}{r}0.127 \\
(0.296)\end{array}$ & $\begin{array}{r}0.121 \\
(0.263)\end{array}$ & $\begin{array}{r}0.179 \\
(0.207)\end{array}$ \\
\hline Firm foreign sales & $\begin{array}{r}0.219 \\
(0.168)\end{array}$ & $\begin{array}{r}0.213 \\
(0.140)\end{array}$ & $\begin{array}{c}0.239 * \\
(0.130)\end{array}$ \\
\hline Firm stock option experience & $\begin{array}{r}0.042 \\
(0.041)\end{array}$ & $\begin{array}{r}0.041 \\
(0.045)\end{array}$ & $\begin{array}{r}0.019 \\
(0.040)\end{array}$ \\
\hline Firm CEOs on board & $\begin{array}{r}-0.004 \\
(0.009)\end{array}$ & $\begin{array}{r}-0.008 \\
(0.010)\end{array}$ & $\begin{array}{r}-0.001 \\
(0.010)\end{array}$ \\
\hline Firm equity owned by other firms & $\begin{array}{r}-0.012 \\
(0.067)\end{array}$ & $\begin{array}{r}-0.035 \\
(0.093)\end{array}$ & $\begin{array}{l}-0.191^{* *} \\
(0.084)\end{array}$ \\
\hline Firm equity owned in other firms & $\begin{array}{r}0.069 \\
(0.100)\end{array}$ & $\begin{array}{r}0.033 \\
(0.098)\end{array}$ & $\begin{array}{r}0.054 \\
(0.088)\end{array}$ \\
\hline Firm director busyness & $\begin{array}{r}-0.071 \\
(0.058)\end{array}$ & $\begin{array}{l}-0.099 * \\
(0.052)\end{array}$ & $\begin{array}{r}-0.082 \\
(0.054)\end{array}$ \\
\hline Firm acquisition experience & $\begin{array}{r}0.022 \\
(0.028)\end{array}$ & $\begin{array}{r}0.000 \\
(0.023)\end{array}$ & $\begin{array}{r}-0.006 \\
(0.020)\end{array}$ \\
\hline Partner's profitability (mean) & $\begin{array}{r}0.289 \\
(0.529)\end{array}$ & $\begin{array}{r}0.468 \\
(0.467)\end{array}$ & $\begin{array}{r}0.292 \\
(0.407)\end{array}$ \\
\hline Partners' foreign sales (mean) & $\begin{array}{r}-0.004 \\
(0.289)\end{array}$ & $\begin{array}{r}-0.144 \\
(0.263)\end{array}$ & $\begin{array}{r}-0.152 \\
(0.228)\end{array}$ \\
\hline Partners' EE experience (mean) & $\begin{array}{r}0.004 \\
(0.015)\end{array}$ & $\begin{array}{r}0.024 \\
(0.017)\end{array}$ & $\begin{array}{r}0.017 \\
(0.018)\end{array}$ \\
\hline Partners' CEOs on board (mean) & $\begin{array}{r}0.041 \\
(0.030)\end{array}$ & $\begin{array}{r}0.025 \\
(0.031)\end{array}$ & $\begin{array}{r}0.019 \\
(0.028)\end{array}$ \\
\hline $\begin{array}{l}\text { Partners' equity owned by other firms } \\
\text { (mean) }\end{array}$ & $\begin{array}{l}-0.196 \\
(0.194)\end{array}$ & $\begin{array}{l}-0.122 \\
(0.163)\end{array}$ & $\begin{array}{l}-0.108 \\
(0.150)\end{array}$ \\
\hline
\end{tabular}




\begin{tabular}{|l|ccc|} 
Partners' equity owned in other firms & 0.041 & -0.253 & -0.123 \\
(mean & $(0.187)$ & $(0.196)$ & $(0.199)$ \\
Partners' director busyness (mean) & 0.015 & -0.013 & -0.028 \\
& $(0.115)$ & $(0.106)$ & $(0.098)$ \\
Sartners' acquisition experience (mean) & -0.023 & -0.016 & -0.027 \\
& $(0.038)$ & $(0.048)$ & $(0.047)$ \\
Firm, Industry, Year FE & -0.001 & -0.000 & -0.001 \\
Constant & $(0.002)$ & $(0.001)$ & $(0.001)$ \\
& $Y$ & $Y$ & $Y$ \\
\hline Sample size (firm-years) & 0.167 & 0.422 & $0.543 *$ \\
Firms in sample & $(0.287)$ & $(0.303)$ & $(0.281)$ \\
AR1 test & 803 & 803 & 803 \\
AR2 test & 71 & 71 & 71 \\
Model Chi2 & $-3.755^{* *}$ & $-4.049 * *$ & $-4.141 * *$ \\
\hline
\end{tabular}


Exequiel Hernandez (exequiel@wharton.upenn.edu) is assistant professor of management at the Wharton School, University of Pennsylvania. He received his PhD from the University of Minnesota. He studies networks and internationalization, particularly how firms manage knowledge and competition distributed across multiple locations and network relationships.

Wm. Gerard Sanders (gerry.sanders@utsa.edu) is Dean and Bodenstedt Chair of the College of Business at the University of Texas at San Antonio. He received his $\mathrm{PhD}$ from the University of Texas at Austin. His research focuses on corporate governance and executive compensation.

Anja Tuschke (tuschke@bwl.lmu.de) is professor and head of the Institute of Strategic Management at the Munich School of Management at the University of Munich. She received her doctoral degree at the University of Passau. Her research focuses on corporate governance, strategic leadership, and international management. 